\begin{tabular}{|l|l|}
\hline $\begin{array}{l}\text { 2. To: (Receiving Organization) } \\
\text { TWRS Facility Operations } \\
\text { Design Authority }\end{array}$ & $\begin{array}{l}\text { 3. From: (Originating Organization) } \\
\text { TWRS Facility Operations } \\
\text { Design Authority }\end{array}$ \\
\hline $\begin{array}{l}\text { 5. Proj./Prog./Dept./Div.: } \\
\text { LLCE Dispoal Program }\end{array}$ & $\begin{array}{l}\text { 6. Design Authority/ Design Agent/cog. } \\
\text { Engr.: P.A. Titzler }\end{array}$ \\
\hline $\begin{array}{l}\text { 8. Originator Remarks: } \\
\text { ETN-94-0054D Document was issued as a draft for comments by } \\
\text { EDT 606495. All comments have been incorporated. }\end{array}$
\end{tabular}

11. Receiver Remarks: 11A. Design Baseline Document? [] res [X] No
4. Related EDT No.:

606495

7. Purchase Order No.:

$$
\mathrm{N} / \mathrm{A}
$$

9. Equip./Component No.:

$$
\mathrm{N} / \mathrm{A}
$$

10. System/Bldg./Facility:

$$
N / A
$$

12. Major Assm. Dwg. No.:

$$
N / A
$$

13. Permit/Permit Application No.: N/A

14. Required Response Date: $1 / 30 / 97$

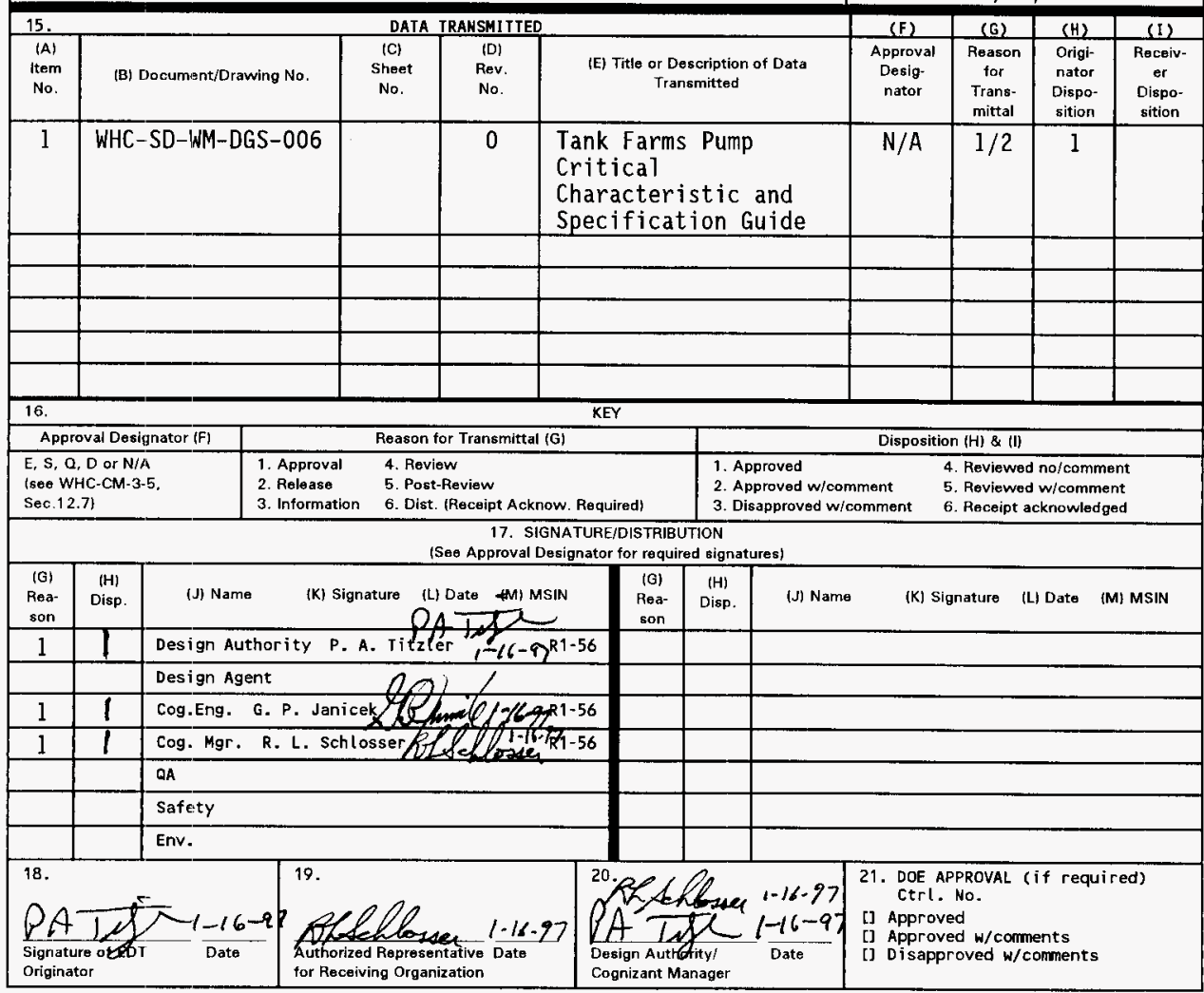




\section{Tank Farms Pump Critical Characteristic and Specification Guide}

S. D. Riesenweber

ARES Corporation, Richland, WA 99352

U.S. Department of Energy Contract DE-AC06-87RL10930

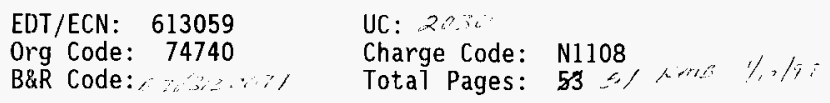

Key Words: Pump, Specification Guide

Abstract: The Design Authority group for Tank Farms, in conjunction with the Construction Projects organization, have recognized that there is a need to provide consistency in the procurement and testing of pumps and to assure that known critical attributes and features are included with each pump order as well as to reduce potential confusion by pump suppliers. As a result, a panel of pump experts representing Lockheed Martin Hanford Company, Fluor Danie] Northwest, Numatec Hanford Corporation, SGN Eurisys Services Corporation, and Ares Corporation has been assembled to prepare a guide for pump specifications.

TRADEMARK DISCLAIMER. Reference herein to any specific commercial product, process, or service by triade name, trademark, manufacturer, or otherwise, does not necessarily constitute or imply its endorsement, recommendation, or favoring by the United States Government or any agency thereof or it $;$ contractors or subcontractors.

Printed in the United States of America. To obtain copies of this document, contact: WHC/BCS Document Control Services, P.0. Box 1970, Mailstop H6-08, Richland WA 99352, Phone (509) 372-2420; Fax (509) 376-4989.
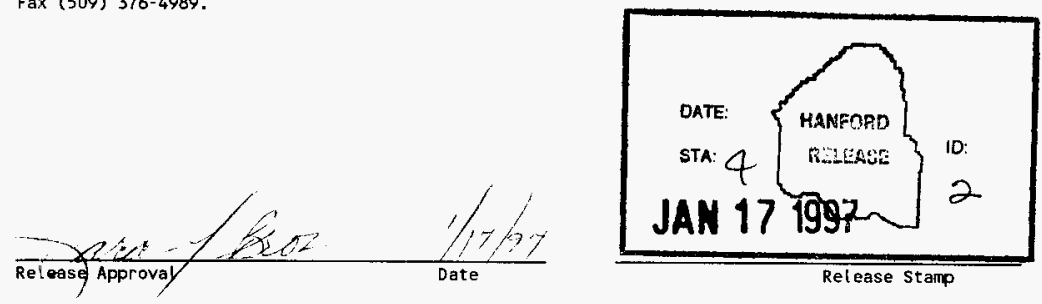

Release stamp 
WHC-SD-WM-DGS-006, Rev. 0

\title{
TANK FARMS PUMP CRITICAL CHARACTERISTIC AND SPECIFICATION GUIDE
}

\author{
Prepared for \\ LOCKHEED MARTIN HANFORD COMPANY \\ Purchase Order MRK-SLB-336070 \\ Task A96-145 \\ Report No. 961145-001 \\ Revision 0
}

January 1997

Prepared by

ARES CORPORATION

636 Jadwin Avenue Suite B

Richland, Washington 99352 
WHC-SD-WM-DGS-006, Rev. 0

\section{CONCURRENCE}

The following individuals participated in the development of this document. The signatures below indicate concurrence with the information contained herein.

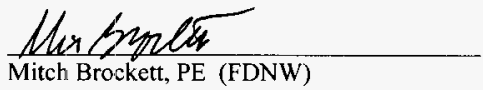

$\frac{\text { Deannis Crass Per tezeron SDR }}{\text { Dennis Crass (lMHC) }}$

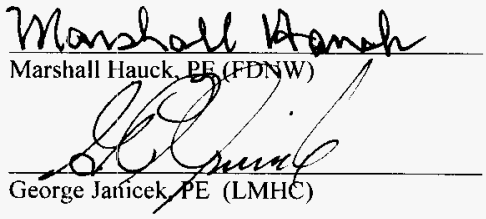

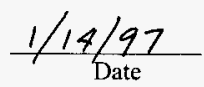
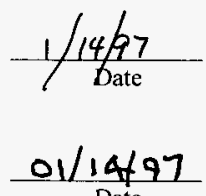

Date

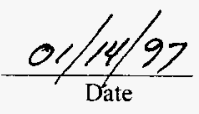
$\frac{\text { DaRRYL LamberA PER TEZECON SIR }}{\text { Darryl Lamberd (NHC) }}$
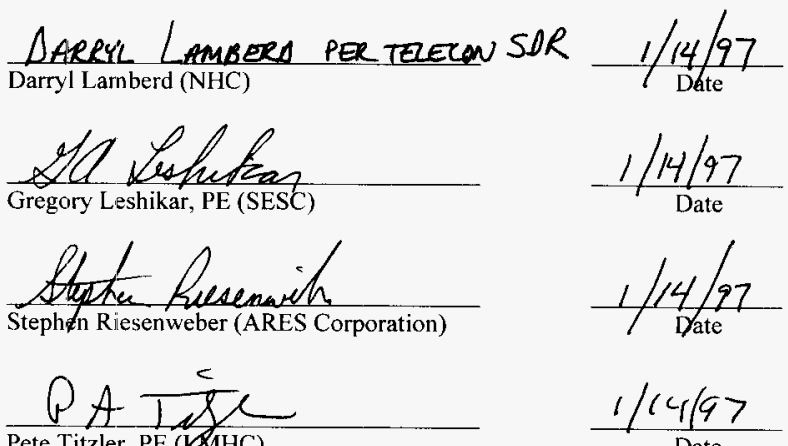

$\frac{1 / 14 / 97}{\text { Date }}$ 


\section{TANK FARMS PUMP CRITICAL CHARACTERISTIC AND SPECIFICATION GUIDE}

Prepared for

\section{LOCKHEED MARTIN HANFORD COMPANY \\ Purchase Order MRK-SLB-336070 \\ Task A96-145 \\ Report No. 961145-001 \\ Revision 0}

Prepared by: Stephen D. Riesenweber

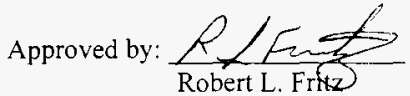

Date: $1-14-9\rangle$ 


\section{ACKNOWLEDGMENTS}

This document was developed through the input and cooperation of all signatories on the concurrence page. All of these individuals have many years of experience working with pumps both at the Hanford Site and within the pump industry. The authors represent a full range of pump experience, including design and development, procurement, selection, installation, operation, maintenance, and troubleshooting.

Several individuals must be acknowledged who, while not authors of this document, provided valuable input in areas where special expertise was deemed necessary. Information on waste characteristics was provided by Graham MacLean (SESC). Input on seismic criteria was provided by William Magruder (FDNW). Also, input was provided on various critical characteristics by Craig Shaw (SESC), Mark Przybylski (FDNW), and Mark Hall (WSRC). 


\section{TABLE OF CONTENTS}

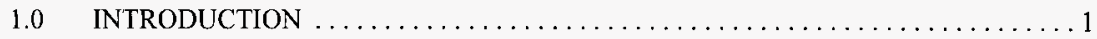

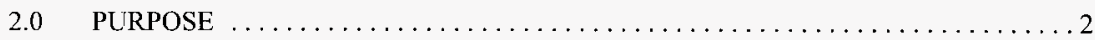

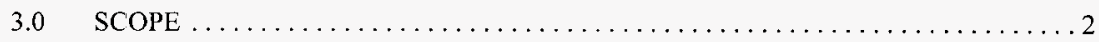

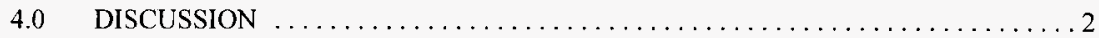

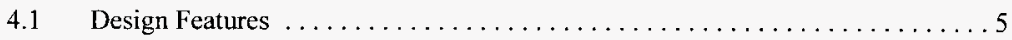

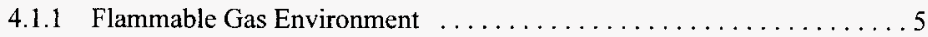

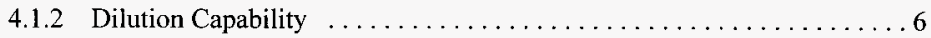

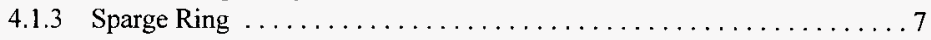

4.1.4 Reverse Flow and Rotation Protection $\ldots \ldots \ldots \ldots \ldots \ldots \ldots \ldots$

4.1.5 Rigging and Handling Single Point Lifts $\ldots \ldots \ldots \ldots \ldots \ldots \ldots \ldots$

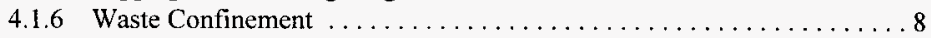

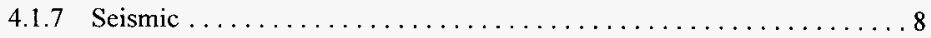

4.1 .8 Flush Capability . . . . . . . . . . . . . . . . . . . . . . . . . 9

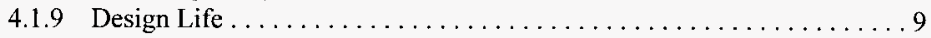

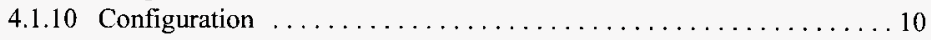

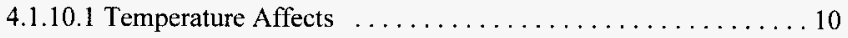

4.1 .10 .2 Process Lubricated Bearings . . . . . . . . . . . . . 10

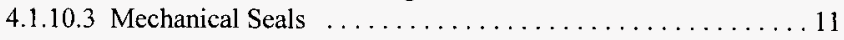

4.1 .10 .4 Dynamics . . . . . . . . . . . . . . . . . . . . . . . 11

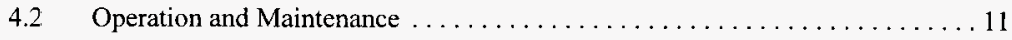

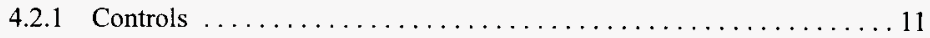

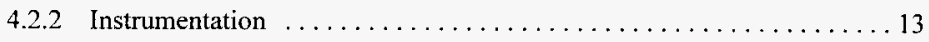

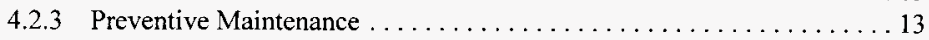

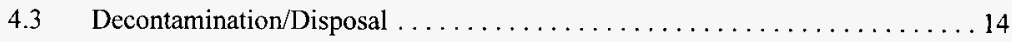

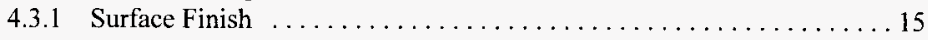

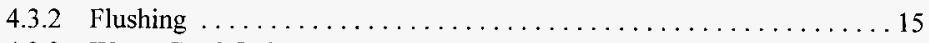

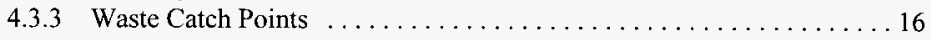

4.3 .4 LLCE Compatible . . . . . . . . . . . . . . . . . . . . . 16

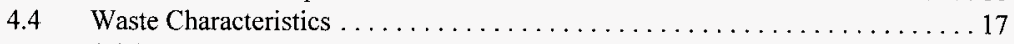

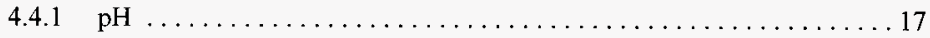

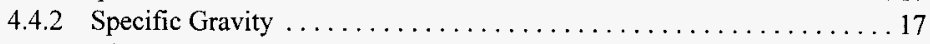

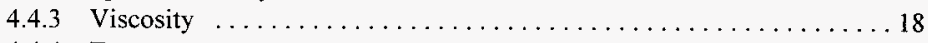

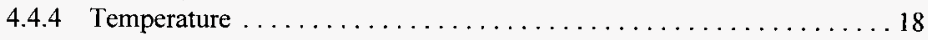




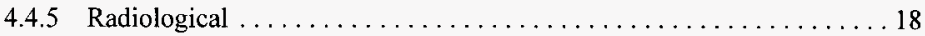

4.4 .6 Chemical . . . . . . . . . . . . . . . . . . . . . . 19

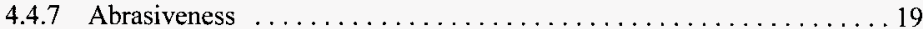

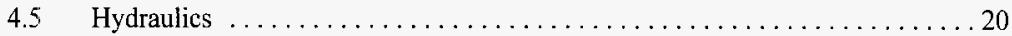

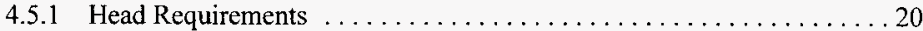

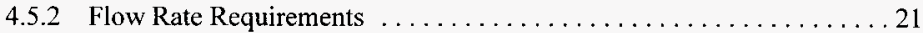

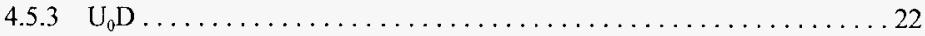

4.5.4 Net Positive Suction Head, available ................. 22

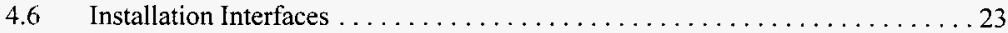

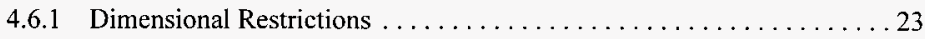

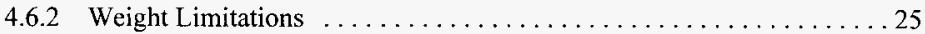

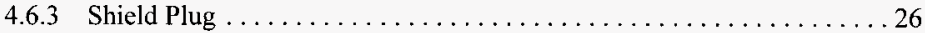

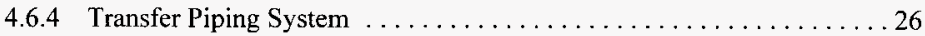

4.6 .5 Utilities . . . . . . . . . . . . . . . . . . . . . . . . 27

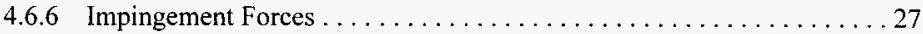

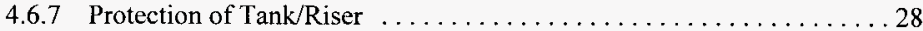

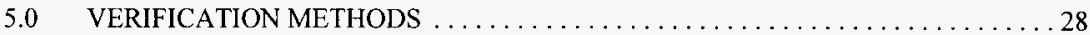

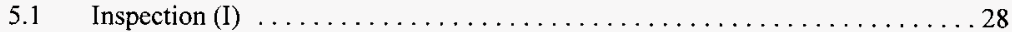

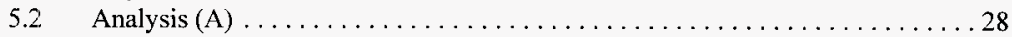

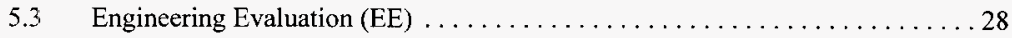

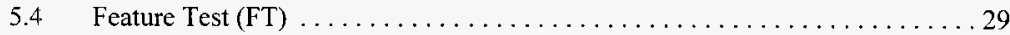

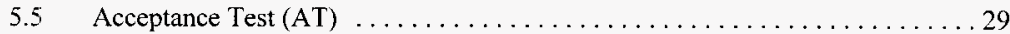

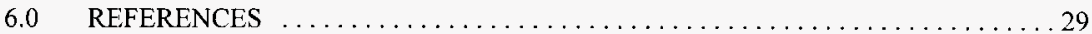

\section{APPENDICES}

Appendix A

Applicable Codes for Centrifugal Pump Procurement $\ldots \ldots \ldots \ldots \ldots \ldots \ldots \ldots$ A-1 Appendix B

Basis for Waste Simulant Choice $\ldots \ldots \ldots \ldots \ldots \ldots \ldots \ldots \ldots \ldots \ldots \ldots \ldots$ 


\section{FIGURES}

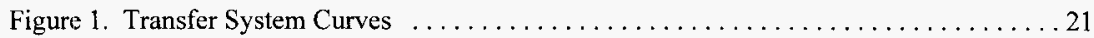

Figure 2. Total Tank Transfer Pumping Arrangement ....................... 24

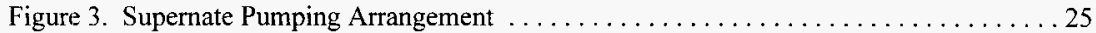

\section{TABLES}

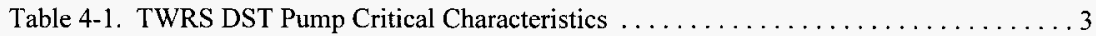

Table 4-2. Equipment Dimensional Constraints . . . . . . . . . . . . . . . . . 16 


\section{ACRONYMS}

$\begin{array}{ll}\text { ALARA } & \text { As Low As Reasonably Achievable } \\ \text { DST } & \text { Double-Shell Tank } \\ \text { EPA } & \text { Environmental Protection Agency } \\ \text { FDNW } & \text { Fluor Daniel Northwest } \\ \text { ICF KH } & \text { ICF Kaiser Hanford Company } \\ \text { JCO } & \text { Justification for Continued Operation } \\ \text { LLCE } & \text { Long-Length Contaminated Equipment } \\ \text { LMHC } & \text { Lockheed Martin Hanford Corporation } \\ \text { NEMA } & \text { National Electric Manufacturers Association } \\ \text { NGTP } & \text { New Generation Transfer Pump } \\ \text { NHC } & \text { Numatec Hanford Corporation } \\ \text { NPSHa } & \text { Net Positive Suction Head, available } \\ \text { OSD } & \text { Operation Specification Document } \\ \text { PNNL } & \text { Pacific Northwest National Laboratory } \\ \text { RCRA } & \text { Resource Conservation and Recovery Act } \\ \text { RMW } & \text { Radioactive Mixed Waste } \\ \text { SAR } & \text { Safety Analysis Report } \\ \text { SESC } & \text { SGN Eurisys Services Corporation } \\ \text { SG } & \text { Specific Gravity } \\ \text { SST } & \text { Single-Shell Tank } \\ \text { TWRS } & \text { Tank Waste Remediation System } \\ \text { VFD } & \text { Variable Frequency Drive } \\ \text { WSRC } & \text { Westinghouse Savannah River Company } \\ & \end{array}$




\section{$1.0 \quad$ INTRODUCTION}

The Flanford Tank Farms consist of 177 underground tanks containing over 50 million gallons of radioactive waste generated during World War II and the Cold War. The current mission of Project Hanford is to safely store, and ultimately accomplish safe and stable long-term disposition of the waste. In order to accomplish this mission, it will continue to be necessary to transfer the waste from location to location for such purposes as: 1) volume management of limited tank storage space, 2) waste volume reduction at an evaporation facility, 3) removal of waste from single-shell tanks (SSTs) to more safe and reliable double-shell tanks (DSTs), and 4) transport to and from pretreatment and final treatment facilities. It is certain that millions of gallons of waste will require mobilization and transport before final cleanup of the Hanford Site is completed.

Waste within the tanks takes the form of liquids, slurries, sludges, and salt cakes--often in combined states. In order to move the more solid forms of waste, it is necessary to mobilize and mix the contents of the tanks creating a fairly homogeneous mixture prior to transfer. The current approach to mixing is through the use of high volume, high velocity oscillating jet, centrifugal mixer pumps.

Waste transfers are made through a network of two- and three-inch pipelines which interconnect Tank Farms and related facilities. Pumps are suspended from risers in the tops of the tank into the waste below; most are approximately 50 to 60 feet long. In the past, transfers were made using relatively inexpensive (i.e., $\$ 30,000$ ) vertical turbine pumps. These pumps had the disadvantage of being relatively low capacity in terms of head and flow which sometimes resulted in plugged transfer lines. Another drawback was the short mean time between failure characteristic of the pumps (averaging approximately 2.5 million gallons per pump). Since the pumps were highly contaminated after use in the waste and were not designed for decontamination or repair, failure normally meant that the pumps were waste and required disposal. At that time, disposal was a relatively simple and inexpensive process. Recent Environmental Protection Agency (EPA) regulations have made this Long-Length Contaminated Equipment (LLCE) disposal both labor intensive and expensive (estimated at $\$ 300,000$ per item once the standardized disposal system is completed).

Because of the increased cost of pump disposal, combined with a known increased future need to mobilize and transport wastes in support of the cleanup effort, it is very important that the Tank Farms and associated projects install optimal transfer and mixer pumps. However, because there are many different projects and people that procure pumps for Tank Farms, and because the nature of the waste to be pumped is not clearly understood and varies from tank to tank, there is currently a disparity between pump procurement specification requirements. 


\subsection{PURPOSE}

The Design Authority group for Tank Farms, in conjunction with the Construction Projects organization, have recognized that there is a need to provide consistency in the procurement and testing of pumps and to assure that known critical attributes and features are included with each pump order as well as to reduce potential confusion by pump suppliers. As a result, a panel of pump experts representing Lockheed Martin Hanford Company (LMHC), Fluor Daniel Northwest (FDNW), Numatec Hanford Corporation (NHC), SGN Eurisys Services Corporation (SESC), and ARES Corporation has been assembled to prepare a guide for pump specifications. This document contains the consensus listing of critical characteristics and procurement recommendations of the panel. It is intended to be used as a guide for future pump procurement activities. If followed, it will help reduce cleanup costs at the Hanford Site and promote prompt approval of pumping system designs and procurement specifications. Alternate criteria may be specified on a case by case basis if deviation from the requirements contained herein is merited due to special circumstances.

\subsection{SCOPE}

The scope of this guidance document is limited to transfer and mixer pumps procured for Tank Farm DSTs. Much of the material contained herein will be beneficial for use during SST sluicing application specification development, but insufficient knowledge of the needs of these future applications makes it necessary to exclude them from this document.

\subsection{DISCUSSION}

An important premise underlying the development of this document is the assertion that, "the more the pump manufacturer knows about the environmental and operational conditions the pump will experience, the more likely it is that the pump received will fulfill all the needs of the application". For this reason, ranges are provided to communicate when a parameter cannot be described as a single point--particularly under "Waste Characteristics" and "Hydraulics".

Table 4-1 is a matrix containing standard critical characteristics for Tank Farm transfer and mixer pumps. The characteristics are divided into six main areas: 1) Design Features,

2) Operation/Maintenance, 3) Decontamination/Disposal, 4) Waste Characteristics,

5) Hydraulics, and 6) Installation Interfaces. These areas are subdivided into elements with specific criteria described for each. Under each element heading is a number reference for a following section of this document which provides additional information on the particular 
critical characteristic. In addition, for each element, a Verification Method(s) is recommended to assure that pumps received comply with the requirements of the specification.

Following Table 4-1 are sections describing the criteria and critical characteristics in more detail, the rationale for the selection, and the source from which the criteria was selected. Wherever possible, specific documents are referenced; however in some cases, no reference document is available. In these cases, the criteria was selected based on the experience and engineering judgement of the committee. This team of engineers has extensive experience working with pumps on and off the Hanford Site; as such, their knowledge base provides a valuable resource that could only be improved upon through an expensive and time consuming testing and characterization program.

While the criteria provided will be applicable to most pump procurement activities, each one must be reviewed during specification preparation to assure that it is appropriate for the particular pumping application being addressed. If the criteria is to be changed, care must be taken to assure that the long-term needs of Project Hanford are considered.

Appendix A provides a listing of codes and standards which are appropriate references to be used in pump procurement, design, and testing. Additional references may be necessary for case specific applications.

Table 4-1. TWRS DST Pump Critical Characteristics

\begin{tabular}{|ll|l|l|c|}
\hline \multicolumn{2}{|c|}{ Application } & \multicolumn{2}{|c|}{ Transfer Pump } & $\begin{array}{l}\text { Verification } \\
\text { Method 5.0 }\end{array}$ \\
\hline 4.1 & DESIGN FE ATURES & \multicolumn{2}{|c|}{ EE } \\
\hline 4.1 .1 & Flammable Gas & $\begin{array}{l}\text { Must meet requirements of the } \\
\text { Flammable Gas JCO }\end{array}$ & $\begin{array}{l}\text { Must meet requirements of } \\
\text { the Flammable Gas JCO }\end{array}$ & A \\
\hline 4.1 .2 & Dilution Capability & $\begin{array}{l}70 \text { gpm @ } 70 \text { psi at pump } \\
\text { suction }\end{array}$ & No & EE \\
\hline 4.1 .3 & Sparge Ring & No & Required & AT \\
\hline 4.1 .4 & $\begin{array}{l}\text { Reverse Rotation \& } \\
\text { Flow Protection }\end{array}$ & Required & Required & A or AT \\
\hline 4.1 .5 & $\begin{array}{l}\text { Rigging and Handling } \\
\text { Single Point Lifts }\end{array}$ & Required & Required & \\
\hline
\end{tabular}




\begin{tabular}{|c|c|c|c|c|}
\hline & Application & Transfer Pump & Mixer Pumps & $\begin{array}{l}\text { Verification } \\
\text { Method } 5.0\end{array}$ \\
\hline 4.1 .6 & Waste Confinement & $\begin{array}{l}\text { Seals, connectors, codes and } \\
\text { standards, hydro test }\end{array}$ & $\begin{array}{l}\text { Seals, connectors, codes and } \\
\text { standards, hydro test }\end{array}$ & $\mathrm{I}, \mathrm{FT}$, or AT \\
\hline 4.1 .7 & Seismic & Required, GC LOAD - 01 & Required, GC LOAD - 01 & A \\
\hline 4.1 .8 & Flush Capability & Required & Required & $\mathrm{EE}, \mathrm{AT}$ \\
\hline 4.1 .9 & Design Life & $5,000 \mathrm{hrs}-10$ years & $5,000 \mathrm{hrs}-10$ years & A, FT \\
\hline 4.1 .10 & Configuration & See section 4.1 .10 & See section 4.1 .10 & $\mathrm{~A}, \mathrm{FT}, \mathrm{EE}$ \\
\hline 4.2 & \multicolumn{4}{|c|}{ OPERATION/ MAINTENANCE } \\
\hline 4.2 .1 & Controls & Variable Frequency Drive & Variable Frequency Drive & EE, AT \\
\hline 4.2 .2 & Instrumentation & Amperage, RPM (VFD) & Amperage, RPM (VFD) & $\mathrm{EE}, \mathrm{AT}$ \\
\hline 4.2 .3 & $\begin{array}{l}\text { Preventative } \\
\text { Maintenance }\end{array}$ & Required & Required & $\mathrm{EE}$ \\
\hline 4.3 & \multicolumn{4}{|c|}{ DECONTAMINATION/ DISPOSAL } \\
\hline 4.3 .1 & Surface Finish & 125 RMS & 125 RMS & I \\
\hline 4.3 .2 & Internal Flushing & Required & Required & EE, AT \\
\hline 4.3 .3 & Waste Catch Points & $\begin{array}{l}\text { Minimize, } \\
\text { Self-draining }\end{array}$ & $\begin{array}{l}\text { Minimize, } \\
\text { Self-draining }\end{array}$ & $\mathrm{EE}, \mathrm{I}$ \\
\hline 4.3 .4 & LLCE Compatible & Required & Required & $\mathrm{EE}$ \\
\hline 4.4 & \multicolumn{4}{|c|}{ WASTE CHARACTERISTICS } \\
\hline 4.4 .1 & $\mathrm{pH}$ & $7-14$ & $7-14$ & $\mathrm{EE}$ \\
\hline 4.4 .2 & SG & $1.0-1.4$ & $1.0-1.6$ & AT or EE \\
\hline 4.4 .3 & Viscosity (cp) & $1.0-30$ Newtonian & $1.0-50$ Newtonian & At or EE \\
\hline 4.4 .4 & Temperature $\left({ }^{\circ} \mathrm{C}\right)$ & $\begin{array}{l}50-200^{\circ} \mathrm{F} \text { liquids } \\
50-220{ }^{\circ} \mathrm{F} \text { sludge }\end{array}$ & $\begin{array}{l}50-200^{\circ} \mathrm{F} \text { liquids } \\
50-220^{\circ} \mathrm{F} \text { sludge }\end{array}$ & AT or EE \\
\hline 4.4 .5 & Radiological & $\begin{array}{l}\text { Above flange } 50 \mathrm{rad} / \mathrm{hr} \text {, } \\
\text { Waste } 1000 \mathrm{rad} / \mathrm{hr}\end{array}$ & Waste $1000 \mathrm{rad} / \mathrm{hr}$ & $\mathrm{EE}$ \\
\hline 4.4 .6 & Chemical & See section 4.4 .6 & See section 4.4 .6 & $\mathrm{EE}$ \\
\hline 4.4 .7 & Abrasiveness & Miller Number 100 max. & Miller Number 100 max. & $\mathrm{AT}, \mathrm{FT}, \mathrm{EE}$ \\
\hline
\end{tabular}




\begin{tabular}{|c|c|c|c|c|}
\hline & Application & Transfer Pump & Mixer Pumps & $\begin{array}{l}\text { Verification } \\
\text { Method } 5.0\end{array}$ \\
\hline 4.5 & HYDRAULICS & & & \\
\hline 4.5 .1 & Head Requirements & $\begin{array}{l}450 \mathrm{ft} \text { max (see graph for } \\
\text { range) }\end{array}$ & $\mathrm{N} / \mathrm{A}$ & AT, A \\
\hline 4.5 .2 & Flow Rate & 140 gpm max. & $\mathrm{N} / \mathrm{A}$ & $\mathrm{AT}, \mathrm{A}$ \\
\hline 4.5 .3 & $\mathrm{U}_{0} \mathrm{D}$ & N/A & $29.4 \mathrm{ft}^{2} / \mathrm{sec} \max$ & $A$ \\
\hline 4.5 .4 & NPSHa & $13.5 \mathrm{ft}$. & $17 \mathrm{ft}$. & $\mathrm{AT}, \mathrm{FT}, \mathrm{A}$ \\
\hline 4.6 & \multicolumn{4}{|c|}{ INSTALLATION INTERFACES } \\
\hline 4.6 .1 & $\begin{array}{l}\text { Dimensional } \\
\text { Restrictions }\end{array}$ & $\begin{array}{l}12 " \text { riser }-11 \text { " max dia. for } \\
\text { pump and column, } \\
\text { Length is tank specific }\end{array}$ & $\begin{array}{l}42 " \text { riser }-39^{\prime \prime} \text { max dia. for } \\
\text { pump and column, } \\
\text { Length is tank specific }\end{array}$ & $\mathrm{I}, \mathrm{EE}$ \\
\hline 4.6 .2 & Weight Limitations & Tank Specific & Tank Specific & $\mathrm{EE}$ \\
\hline 4.6 .3 & Shield Plug & No & Required & $A$ \\
\hline 4.6 .4 & $\begin{array}{l}\text { Transfer Piping } \\
\text { System }\end{array}$ & Pressure Limited & $\mathrm{N} / \mathrm{A}$ & $\mathrm{EE}$ or $\mathrm{A}$ \\
\hline 4.6 .5 & Utilities & Tank Specific & Tank Specific & $\mathrm{EE}$ \\
\hline 4.6 .6 & Impingement Forces & Application Specific & Application Specific & $A$ \\
\hline 4.6 .7 & Tank Riser Protection & Tank Specific & Tank Specific & A \\
\hline
\end{tabular}

Verificaltion Methods:

$\begin{array}{llll}\text { I Inspection } & \text { A } & \text { Analysis } \\ \mathrm{EE} & \text { Engineering Evaluation } & \text { FT } & \text { Feature Test }\end{array}$

AT Acceptance Test

\subsection{Design Features}

\subsubsection{Flammable Gas Environment}

Mixer and Transfer Pumps - Compliance with Flammable Gas/Slurry Growth Unreviewed Safety Question: Justification for Continued Operation for the Tank Farms at the Hanford Site, WHC-SD-WM-JCO-007, Rev. 0 (Leach 1996), is mandatory. Most tank applications will require that pumps shall meet Justification for Continued Operation 
(JCO) requirements for Facility Group 2. Currently, tanks AN-103, AN-104, AN-105, AW-101, and SY-103 are included in Facility Group 1. This classification can and probably will change with time; therefore, the JCO and/or Safety Analysis Report (SAR) should be consulted to determine the appropriate controls.

\subsubsection{Dilution Capability}

Mixer Pumps - Not required.

Transfer Pumps - Transfer pumps shall be specified to include a water addition feature that will provide waste dilution capability at the pump suction. A recommended dilution water flow rate is $70 \mathrm{gpm}$ at $70 \mathrm{psi}$ supply pressure; this will supply a 1:1 dilution ratio in a three inch transfer line at a flow rate of $140 \mathrm{gpm}$.

Dilution water will be introduced at the pump suction. Care must be taken within the design to assure that there is no potential for communication between the pump discharge and the dilution water line; under no conditions should there be a potential to pressurize the dilution water line with the pump discharge pressure.

Waste is known to stratify in the tanks into layers which have varying viscosities and consistencies--some tanks are fairly homogeneous, others are not. Layers can range from a peanut butter-like sludge, to a light flocculent consistency, to clear liquids or anything in-between. Often the pump suction is resting in the more dense material at the bottom of the tank. For this reason, it is very important that water be available at the pump suction to provide some means of diluting the waste to assure that transfer lines do not plug and to clear the suction inlet prior to startup.

The required dilution flow rate critical pump characteristic is not intended to specify a flow that will provide sufficient dilution for all transfers; the rate must be determined as is appropriate to the particular waste to be transferred. The critical characteristic rate provided is based on engineering judgement, historical dilution needs, and discussions with the pumping system cognizant engineer, and is anticipated to meet most transfer needs. Increasing the dilution water pressure above $70 \mathrm{psi}$ will make it possible to achieve a higher flow rate; this may be used if it is determined that a ratio greater than 1:1 is needed.

Project W-058, Replacement Cross-Site Transfer System, generated a Pacific Northwest National Laboratory (PNNL) letter report entitled, Defining Waste Acceptance Criteria for the Hanford Replacement Cross-Site Transfer System, PNNL-11146, UC-2030 
(Hudson 1996). This report delineates the process and analysis for characterizing the waste and determining head and flow requirements and other critical parameters that will assure non-plugging of the cross-site transfer line prior to transfers.

\subsubsection{Sparge Ring}

Mixer Pumps - A sparge ring shall be installed on the bottom of all mixer pumps to facilitate installation. This ring shall be located on the bottom of the pump volute or suction bell. It will have water jets designed to loosen waste sludge packed on the tank bottom sufficiently to open an area which will allow pump installation and adequate flow to the pump suction at startup. This type of arrangement has been used successfully in many past pump installations.

\subsubsection{Reverse Flow and Rotation Protection}

Mixer and Transfer Pumps - Pumps shall be protected so that reverse fluid flow through the pump or reverse rotation does not cause damage. Experience at Tank Farms has shown that reverse flow and rotation occurs as a result of a number of factors, including back flushing prior to startup and after shutdown, drain back due to transfer line holdup and elevation differences when pump is shut off, and incorrect phase connection during wiring. Line shaft driven pumps have been known to have shaft couplings unscrew due to reverse rotation thereby making the pumps permanently inoperable.

\subsubsection{Rigging and Handling Single Point Lifts}

Mixer and Transfer Pumps - All pumps shall be designed such that they may be up righted from a horizontal position by a crane from a single point on the mounting flange end without damage to the pump or its components. A fixture may be provided by the pump manufacturer that protects the pump lower unit during the process of up righting the pump. If a fixture is provided, it must be readily detachable in the field from ground level. The use of a full length strong back should be avoided.

This characteristic is driven by past Tank Farms experience with line-shaft driven pumps. Bearings and pump columns have been damaged during the up righting process. As a result, double picking using two cranes has become the standard practice. In most cases, double picking is not an optimal approach due to the congested nature of the Tank Farms which makes the logistics of positioning two mobile cranes and one flatbed trailer extremely difficult. A pump designed for a single point pick will be capable of a double multiple point pick if that method of up righting is selected during testing or installation. 


\subsubsection{Waste Confinement}

Mixer and Transfer Pumps - All pumps shall be designed to preclude leakage above the pump mounting plate. Seals, if used, shall be designed to direct any potential leakage back into the tank. Vendor testing shall include all pressure boundaries and follow industry recognized codes and standards (see Appendix A).

If water or gas flooded columns are to be used, measures must be taken to assure that failure of a seal on the column cannot pressurize or allow tank waste into the column. The design shall also eliminate the potential for backflow of waste into the gas or water supply lines.

Transfer Pumps - Pump discharge connections will be welded (no flanges) which will normally be terminated by welded connection to a buyer supplied PUREX jumper connector (drawing H-2-32433).

This requirement is based on good ALARA practices. Transfer pump motors and discharge piping are enclosed within a pit that drains back into the tank if a leak occurs. However, waste spilled in the pit will create a radiological hazard which must be cleaned up prior to changing a pump or jumper or any other work to be performed.

\subsubsection{Seismic}

Mixer and Transfer - Pumps shall be designed and analyzed to withstand a seismic event of a magnitude and amplitude appropriate to the pump safety class. In most cases, pumps do not need to continue to run during an event or be operable after the fact. The current exception to this is the tank 101-SY mixer pump which is performing a safety function to mitigate hydrogen gas buildup in the waste. All pumps need to be removable from the tank after the event and must be analyzed to assure that they will not damage the tank riser, tank, or pit.

In most cases, pumps are classified as General Service while the risers and pits are Safety Class or Safety Significant. Analysis must take into account the impacts pumps may have on these safety related systems, structures, and components. The Authorization Basis for the tank that a pump is being installed into shall be consulted to determine the safety classification and function of the interfacing components. ICF Kaiser Hanford Company (ICF KH) Standard GC-LOAD-01, Design Loads for Facilities (ICF KH 1994), provides the seismic criterion based on the safety assessment. 


\subsubsection{Flush Capability}

Mixer Pumps - Provisions to flush the pump internals shall be provided. This feature clears accumulated solids from the hydraulic end of the pump prior to starting after a prolonged downtime or prior to removal of the pump from the tank.

Transfer Pumps - Pumps shall be designed to support back flushing through the pump discharge prior to startup and removal from the tank. For crucial and/or low flow areas, the pump should be equipped with a separate internal flush system with ports in appropriate locations to maximize effectiveness in removing crystals and debris.

Internal flushing of transfer pumps has two primary purposes:

1. Flushing is necessary to facilitate pump removal and disposal as indicated in section 4.3.2, from an ALARA perspective, and

2. It is likely that the collection of abrasive solids and crystals in close-toleranced process lubricated bearings accelerated pump wear and failure when a pump was started up after prolonged lay up in a tank. This phenomenon has contributed to the short life-cycle historically experience by most Tank Farm transfer pumps. Engineering judgement has been used to establish this observation; it has not been verified because of ALARA concerns associated with disassembling highly contaminated equipment after pump failure. However, two recent incidents at tanks 104-AW and 102-AY confirm this belief. Both pumps were frozen when attempts were made to start them after a long lay up; one pump was freed after prolonged flushing with hot water, and the other had its drive shaft broken during attempts to free it.

\subsubsection{Design Life}

Mixer and Transfer Pumps - Pumps shall be specified to have a minimum design life of 5,000 hours of operation over a ten-year period. This duration will include repeated operational cycles with multiple stop/starts followed by extended lay up periods of up to three years. During lay up, the pump will be left submerged in tank waste--often with no periodic flushing. Note that it is necessary to specify that pump components cannot be disassembled and parts replaced during the design life.

The design life duration was developed by the pump committee using such planning documents as the Preliminary Retrieval Sequence and Blending Strategy, WHC-SD-WM- 
RPT-001, Rev. 0 (Certa 1995), and Title I Design Summary Report, Initial Tank Retrieval Systems, Project $W-211$, WHC-SD-W211-TDR-00,1 Rev. 0 and Rev. 0B (Rieck 1995). In addition, knowledge of historical pumping patterns and engineering judgement of the committee were used to determine the reasonable time duration. Additional information came from a cost benefit analysis which compared the continued use of the existing style vertical turbine pumps to that of the New Generation Transfer Pump (NGTP) currently being developed, entitled New Generation Transfer Pump Cost Benefit Analysis, WHCSD-WM-ES-365 Rev. 0 (Brockett 1995). The NGTP has a design life of 10,000 hours of operation over ten years. The analysis showed a savings of approximately $\$ 62$ million over the life of the Tank Farms by the use of the new pump. The primary factor producing savings is the extended life of the pump. Subsequent review of this analysis shows that the bulk of the savings takes place in the first 5,000 hours of extended design life because only one tank will require operation of transfer pumps in excess of 5,000 hours over the anticipated Tank Waste Remediation System (TWRS) mission. For this reason, the design life specified for this document was reduced. A similar analysis entitled Life-Cycle Cost Analysis of Advanced Design Mixer Pump, WHC-SD-WM-CBA001, Rev. 0 (Hall 1996), was performed for mixer pumps; it resulted in design life conclusions consistent with the transfer pump analysis.

\subsubsection{Configuration}

\subsubsection{Temperature Affects}

Pump acceptance performance and run-in testing shall be performed with the pump assembled to its full-length configuration. Testing shall be performed at design temperatures at least for the first prototype pump design. Testing may be performed at the manufacturer's facilities or at the Hanford Site. Final acceptance of the pump from the manufacturer should not be made until after testing is successfully completed.

\subsubsection{Process Lubricated Bearings}

Where process lubricated bearings are used, they shall be designed for worst case waste conditions (see section 4.4), and a test simulant shall be used to initially validate a particular design. Bearing design shall minimize the accumulation of settled solids, and provisions shall be made for flushing during prolonged downtime and prior to restart. 


\subsubsection{Mechanical Seals}

Seals tend to be the highest failure item in any pump. Where seals are used, they shall be designed for worst case waste conditions (see section 4.4), and a test simulant shall be used to initially validate a particular design. If comparable prior testing has been performed by the manufacturer, it may be used as validation of the seal adequacy at the discretion of the Buyer's Technical Representative. Seal design shall minimize the accumulation of settled solids and provisions shall be made for flushing during prolonged downtime and prior to restart.

\subsubsection{Dynamics}

Pumps shall be designed to preclude damage due to operation at critical speeds. This may be accomplished through a combination of rotordynamic analysis based on the physical geometry of the pump and speed exclusion zones programed into the Variable Frequency Drive (VFD).

Radial shaft movement, both deflection and run out, shall be limited as required by API 610 and shall be within the acceptable operating limits of the shaft, seals, and bearings.

\subsection{Operation and Maintenance}

\subsubsection{Controls}

Mixer and Transfer Pumps - All pumps shall be controlled with a VFD matched to the motor installed on the pump. The VFD shall provide soft start capability and shall be capable of operating the pump from a minimum speed of approximately 25 percent speed to full speed operation.

The user should consult with the manufacturer of the VFD to consider factors such as harmonics, excess ground current, and electromagnetic radiation when placing VFDs greater than 200 feet from the motor. VFDs mounted inside conditioned facilities shall meet National Electric Manufacturers Association (NEMA) 12 or ventilated and filtered NEMA 1 requirements. VFDs positioned in the field adjacent to the pump pit shall meet NEMA 3 or NEMA 4 requirements or be provided with environmentally controlled mini enclosures.

Variable frequency drives are required in both mixer and transfer pumps for a number of reasons: 
- Using soft start (increasing the amount of time it takes for the pump to come up to speed) will allow fluid to reach process lubricated bearings prior to full speed operation, thereby reducing wear on pump components.

- The velocity at the mixer pump discharge can be varied depending upon the required cleaning radius; this may be beneficial since it is believed that less mixing will be required to keep waste solids suspended than is needed to accomplish initial mobilization. This speed reduction will reduce heat input to the waste, thereby minimizing the potential for waste temperatures to approach Operation Specification Document (OSD) limits. Further, it may be necessary to slow the mixer pump to reduce impingement forces acting on in tank components. PNNL Letter Report 7W21-87-15, Rev. 0, entitled, Development and Demonstration of Technology for Retrieving Waste From Double-Shell Tanks (Fow 1987), sheds further light on the waste mixing strategy.

- $\quad$ The ability to reduce the mixer pump speed will provide a means of preventing pump cavitation as the tank level is reduced during combined mixing and transfer operations.

- Variable speeds on transfer pumps enhance pump life by allowing them to be operated at a speed which will achieve the desired waste flow rate while running the pump near its best efficiency point. Reducing the pump speed to the minimum required for a given route/destination will also reduce pump wear thereby increasing pump life.

Transfer pumps are required to pump to multiple destinations at Tank Farms and processing facilities. The head required to achieve the minimum flow rate varies depending upon waste characteristics, elevation changes, and piping system restrictions from one destination to another. With single speed pumps, there is a fixed curve which represents the head/flow capabilities of a given pump. For example, a long transfer (i.e., AN Farm to AP Farm) will have a relatively high system head requirement, resulting in the pump running to the left on its performance curve and producing a low flow rate. Conversely, on a short transfer (i.e., between two adjacent tanks within a farm), the system head requirement will be very low causing the pump to run to the right on its curve and resulting in a very high flow rate. Since no control valves exist within the transfer system, this means that pumps will seldom operate near their best efficiency points (the specified head and flow design point). Unfortunately, deviation from a pump's best efficiency point can create abnormal thrusts, cavitation, recirculation, or 
erosion within a pump thereby reducing its Mean Time Between Failure. A VFD allows the pump to be slowed down, resulting in a series of pump performance curves. Thus the desired flow rate can be achieved while maintaining the pump near its best efficiency point.

Transfer Pumps - VFDs shall be equipped with a dropping relay which will be tied to the existing "Master Pump Shutdown System". This system is a control network designed to immediately shut down of the pump if a leak or other anomaly is detected within the transfer system.

\subsubsection{Instrumentation}

Mixer and Transfer Pumps - The pump manufacturer shall provide fixed, non-rotating, environmentally protected field terminations for all power and signal connections. Field terminations shall comply with applicable NEC codes and standards. As a minimum, all pumps shall be instrumented to provide remote readout of pump motor amperage and pump shaft rotational speed. Readouts may be obtained through the VFD. The basis for this requirement is standard engineering practices and experience-based engineering judgement.

Mixer Pumps - Mixer pump turntable mechanisms shall be instrumented to display mixer pump rotational speed in rpm and nozzle orientation. For pump testing, the manufacturer should provide means to fix or attach flow measurement instrumentation on the discharge nozzle.

\subsubsection{Preventive Maintenance}

Pump components mounted below the mounting flange will not be accessible for maintenance or repair once the pump is installed into a tank. All below-the-flange components, such as bearings and seals, shall require no maintenance during the design life of the pump. This is required to comply with ALARA practices.

Pump components above the mounting flange may have a minimal amount of hands-on maintenance based on the manufacturer's recommendations. Access to these components will be severely limited since all transfer pumps and a few mixer pumps are located in pits which are radioactively contaminated. Manned access to these pits is not desirable from an ALARA perspective.

After installation, it is recommended that pumps be rotated or "bumped" on a monthly 
basis between operating campaigns. The pump manufacturer shall provide additional procedures, as necessary, for keeping the pump in optimal condition during this lay up. This recommendation is based on experience with pumps that have "frozen up" during periods of extended inactivity. It is believed that bumping pumps regularly will flush out a portion of the solids that may be packing into the pump internals and break up crystals that may be forming.

Prior to installation in a tank, in most cases, pumps will be stored in a horizontal position for extended periods (i.e., one to five years), the manufacturer shall include maintenance/ storage/handling procedures to prevent damage to shafts, seals, and bearings during this period. Necessary strong backs or jigs required for horizontal storage shall be provided by the pump manufacturer. Hands-on maintenance on the entire pump is possible during this time period.

\subsection{Decontamination/Disposal}

Disposal costs for LLCE removed from waste tanks (including pumps) have increased dramatically with the advent of the EPA Debris Rule (40CFR 268.45 Code of Federal Regulations, Treatment Standards for Hazardous Debris). This law requires that equipment which has been in contact with mixed waste be disposed of as mixed waste. Initial estimates indicated an average disposal cost of approximately $\$ 1.75$ million per item. A recent effort to standardize the cradle-to-grave LLCE disposal process has resulted in a system which is estimated to cost approximately $\$ 300,000$ per item. This is a significant cost which merits consideration during the specification of pumps. Ways to minimize the frequency of need to dispose of pumps, the volume of waste generated when disposal is required, and the amount of exposure personnel will receive during the disposal operation should be included in the pump selection process. A cost benefit analysis was performed in 1995 entitled, New Generation Transfer Pump Cost Benefit Analysis, WHC-SD-WM-ES-365, Rev. 0 (Brockett 1995). It dealt with the benefits of extending the life cycle of transfer pumps. It indicates a $\$ 62$ million savings over the duration of the TWRS mission by using a long-life pump rather than the pump technology currently in use at Tank Farms.

The LLCE process does not include decontamination of equipment in order to exit Resource Conservation and Recovery Act (RCRA) by the EPA Debris Rule criteria. Instead, it involves disposal as radioactive mixed waste (RMW) in existing RCRA approved mixed waste trenches located on the Hanford Site. Disposal in these trenches requires that "free liquids" be removed from equipment but not solid contamination. Thus, decontamination of pumps is required primarily from an ALARA perspective to reduce the dose received by personnel during the removal, packaging, transport, and disposal process. The majority of pumps removed from 
waste tanks will normally be packaged and transported directly to disposal without any cleaning or disassembly beyond what is accomplished by the LLCE retrieval system.

Pumps installed in waste tanks are highly contaminated both internally and externally. For this reason, repair of wetted portions of the pump has not been, and still is not, considered a good alternative based on ALARA and cost perspectives. Thus, pumps that cannot be simply repaired from above the mounting flange are considered failed and must be disposed.

Critical characteristics identified for decontamination and disposal have been divided into the subcategories listed below.

\subsubsection{Surface Finish}

Mixer and Transfer Pumps - The surface finish of all internal and external wetted pump components shall be 125 RMS or better. Parts that will not likely contact the waste may be finished to whatever is standard for the manufacturing process; this will help keep equipment manufacturing costs to a minimum.

The 125 RMS surface finish was selected based on engineering judgement. It was decided upon as a balance between the higher manufacture costs required to achieve a much smoother finish and the degree of decontamination benefit received. While this finish is not ideal for 100 percent contamination removal, it is recognized that 100 percent waste removal is not necessary for disposal of equipment and that hands-on maintenance will not be performed on the wetted parts of pumps. The primary motivator for this criteria is ALARA concerns; the finish selected can be cleaned sufficiently to reduced the radiation to acceptable levels.

\subsubsection{Flushing}

Mixer and Transfer Pumps - A means of internally flushing the pump bowl or volute shall be incorporated into the pump design. Flushing will be performed prior to, and possibly during, removal of the pump from the tank. This feature is needed to reduce contamination levels from an ALARA perspective and to assure that there is a clear path through the pump to allow drainage of free liquids (i.e., the suction is not plugged with solids).

The retrieval equipment included as part of the LLCE process will wash the externals of the equipment during the retrieval process. A 360 degree wash ring will spray the pump with hot water at pressures up to $3,000 \mathrm{psi}$ at $150^{\circ} \mathrm{F}$. 


\subsubsection{Waste Catch Points}

Mixer and Transfer Pumps - Both internal and external cracks, crevices, and hold-up points shall be minimized on the pump to facilitate pump cleanup for disposal. This feature should be specified in the procurement specification and verified during approval of the pump design.

Pumps shall be free draining. Low points which could trap or hold up any liquid waste shall be eliminated from the pump design. Federal requirements for disposal of this type of equipment in a land disposal facility require that all "free liquids" be removed prior to disposal ( 40 CFR 264.314 and 265.314). A Herculite bag is used as the primary container during retrieval; it contains absorbents to catch relatively small quantities of liquids; but these absorbents are added as a backup. The design should be reviewed to assure that the "free liquid" criteria is met.

\subsubsection{LLCE Compatible}

Mixer and Transfer Pumps - The LLCE system has parametric limitations that shall be adhered to by new equipment. Dimensional constraints are controlled by the disposal container sizes that are being procured for the LLCE process in Commercial Specification for the Container Equipment Burial Containers, WHC-S-0402, Rev. 2 (McCormick 1995). Sizes are summarized in Table 4-2 below.

Table 4-2. Equipment Dimensional Constraints

\begin{tabular}{|c|c|c|}
\hline $\begin{array}{c}\text { Burial } \\
\text { Container } \\
\text { Diameter }\end{array}$ & $\begin{array}{c}\text { Maximum Equipment Outside } \\
\text { Diameter }\end{array}$ & $\begin{array}{c}\text { Maximum Equipment Length (two lengths } \\
\text { available for most diameters) }\end{array}$ \\
\hline $26^{\prime \prime}$ & $16.39^{\prime \prime}$ & $68^{\prime} 11^{\prime \prime}$ \\
$52^{\prime \prime} 8^{\prime \prime}$
\end{tabular}


* Containers for this diameter of equipment are not yet designed or procured. However, the tilt and transport trailers have been sized to accommodate all sizes of containers listed. The maximum weight for equipment installed in LLCE packages is $26,000 \mathrm{lbs}$. Analysis must be performed prior to lifting of the burial container for proper location of rigging straps.

** Current retrieval equipment design limits the maximum diameter of equipment to be extracted from a tank to less than 50 inches. Future retrieval equipment must be added to the LLCE system to accommodate larger diameters.

In some cases, it may be possible to remove portions of the equipment for reuse or packaging to facilitate generation of smaller waste volumes by placing the pump in a smaller diameter container. Where practical, this approach should be used since it could result in significant savings for equipment disposal due to waste volume minimization.

\subsection{Waste Characteristics}

\subsection{1 pH}

Mixer and Transfer Pumps - SST waste solutions can range anywhere from moderately alkaline, $\mathrm{pH}=10$, to very basic, $\mathrm{pH}>14$ [Status Report: Pretreatment Chemical Evaluation-Wash and Leach Factors for the Single-Shell Tank Waste Inventory, PNNL11290 (Colton 1996)]. DST specifications require that the hydroxide ion concentration be at least .01 Mol/L (OSD-T-151-00007). In-tank leaching of waste sludges may require hydroxide ion concentrations up to $3 \mathrm{Mol} / \mathrm{L}$, TWRS Privatization Process Technical Baseline, WHC-WM-TI-774 (Orme 1996). Therefore, pump materials of construction need to be durable anywhere in the range from $\mathrm{pH}=10$ up to a hydroxide ion concentration of $3 \mathrm{Mol} / \mathrm{L}$. Since there will be cases where the pump will be operated in water rather than waste (such as during run-in and testing), a minimum $\mathrm{pH}$ of 7 shall be specified.

\subsubsection{Specific Gravity}

Mixer and Transfer Pumps - Pumpable tank wastes can have an average specific gravity varying from that of water with a specific gravity of 1.0 , to that of a slurry made up of a combination of saturated sodium nitrate solution, with a S.G. $=1.46$, and approximately $10 \mathrm{wt} . \%$ insoluble solids, with a $\mathrm{SG}=3.5$. The resulting slurry specific gravity is approximately 1.6 . 
Mixer pumps may be required to pump any of the waste with no dilution. Thus, for these pumps, the waste specific gravity can range from 1.0 to 1.6 . Waste will be diluted as necessary to assure that transfer lines do not plug; as such, a specific gravity range of 1.0 to 1.4 is sufficient for transfer pumps.

\subsubsection{Viscosity}

Mixer and Transfer Pumps - The apparent viscosity of tank waste slurries can vary over a wide range. These slurries can be non-Newtonian, and the apparent viscosity can approach $10,000 \mathrm{cP}$ at shear rates $<1 / \mathrm{sec}$. This creates a problem when specifying pumps. Tank wastes are shear thinning, so as a pump impeller is accelerated, the viscosity decreases. Normally, the maximum apparent viscosity at about $100 / \mathrm{sec}$ shear rate is used for pump design, since waste slurry viscosities do not decrease substantially as the shear rate is increased beyond this value. Generally, slurries to be transferred will not exceed $30 \mathrm{cP}$ at $100 / \mathrm{sec}$, and slurries drawn into mixer pumps should not exceed $50 \mathrm{cP}$.

\subsubsection{Temperature}

Mixer and Transfer Pumps - Pumps shall be capable of operating with waste temperatures ranging from $50^{\circ} \mathrm{F}$ to $200^{\circ} \mathrm{F}$ in the tank liquid regions. Sludge temperatures can range from $50^{\circ} \mathrm{F}$ to $220^{\circ} \mathrm{F}$. It should be noted that when sludge is to be transferred, cooler (i.e., $50^{\circ} \mathrm{F}$ ) raw water will be added to dilute the solution; this will result in waste at or below the maximum liquid temperatures flowing through the transfer pump. The maximum temperatures were taken from the draft report, Aging Waste Facility Ventilation Upgrade, Project W-030 Safety Analysis Reference Report, WHC-SD-WMSARR-039 Rev. 0 (Guthrie 1996). This report was selected because the aging waste tanks, being the Tank Farm's "high-heat" tanks, have the bounding high temperature conditions.

\subsubsection{Radiological}

Mixer and Transfer Pumps - Radiation levels in tank wastes span from low to very high. The highest levels are found in tank AZ-101, which contains PUREX waste. In-tank processing could result in wastes with activities similar to tank AZ-101, but not likely higher, with the possible exception of concentrated cesium solution from the regeneration of cesium removal ion exchangers. Levels in tank AZ-101 sludge have been measured as high as 1,000 Rad/hr with a drywell scan, while maximum levels possible above a riser flange have been estimated to be $50 \mathrm{Rad} / \mathrm{hr}$. With the exception of cesium regeneration 
waste, the design requirements should be $1,000 \mathrm{Rad} / \mathrm{hr}$ maximum in the waste, and 50 $\mathrm{Rad} / \mathrm{hr}$ maximum above any riser flange.

\subsubsection{Chemical}

Mixer and Transfer Pumps - Tank wastes can have a great variety of chemical compositions, both in species present and concentration. Waste composition in the carbon steel waste tanks must be controlled to prevent stress and crevice corrosion and pitting, and to minimize uniform corrosion, Pretreatment Applied Engineering, Corrosion Assessment for Tank Materials: 1995 Final Report, WHC-SD-WM-TI-765 Rev.0, (MacLean 1996). The main chemical specie responsible for tank corrosion is the nitrate ion. Tank wastes can contain up to $60 \mathrm{wt} \%$ sodium nitrate, or $10 \mathrm{Mol} / \mathrm{L}$. Nitrite and hydroxide ions, which inhibit corrosion, are maintained at concentrations that negate the effect of the nitrate (OSD-T-151-00007, 00017). Pump materials of constructions should be resistant to corrosion in solutions with the following maximum concentrations: nitrate $=10 \mathrm{Mol} / \mathrm{L}$, nitrite $=3 \mathrm{Mol} / \mathrm{L}$, and hydroxide $=3 \mathrm{Mol} / \mathrm{L}$ (as in section 4.4.1).

Chloride ion is of special concern. There is evidence that $.5 \mathrm{Mol} / \mathrm{L}$ chloride can cause substantial corrosion of carbon steel in the vapor space above waste or at liquid-gas interfaces (MacLean 1996). Concentrations in tank wastes have been estimated to be less than .02 moles chloride per mole of sodium for all tanks except tank SY-101, which is .03 . For a maximum sodium concentration of $10 \mathrm{Mol} / \mathrm{L}$, the maximum chloride generally will be $<.2 \mathrm{Mol} / \mathrm{L}$, or $7 \mathrm{~g} / \mathrm{L}$. Thus, pump materials of construction should be resistant to corrosion in solutions with up to $.2 \mathrm{Mol} / \mathrm{L}$ chloride ion.

\subsubsection{Abrasiveness}

Mixer and Transfer Pumps - It is difficult to specify one value of abrasiveness that is suitable for all pumps. Some wastes can be much more abrasive than others due to large amounts of sand or other hard particles. Very abrasive slurries could require much more expensive materials of construction or designs than more mild metal hydroxide only slurries. Based on waste analyses and very limited tests, a specification with a maximum Miller Number of 100 should be appropriate for most wastes. However, it should be noted that the Miller Number of waste pumped could range from 0 to 100 per ASTM G75-95.

An additional method for specifying the abrasiveness of the waste is to provide a simulant test formula with maximum concentrations of sand (Quartz) and crystalline sodium aluminosilicate (Albite), the two most abrasive materials found in tank wastes. 
The concentrations which were used for the transfer pump bearing tests are deemed to be appropriate. The constituents and concentrations of materials used are provided in Appendix B.

Note: Alumina is not present in tank wastes unless it was put in as alumina. Alumina, $\mathrm{Al}_{2} \mathrm{O}_{3}$, is made by calcining aluminum hydroxide at high temperatures. It cannot form from the precipitation of gibbsite, boehmite, or other oxyhydroxides of aluminum in an aqueous environment. Frequently, the aluminum content of a waste is reported as "A.lumina", but this is for convenience or by convention, not because $\mathrm{Al}_{2} \mathrm{O}_{3}$ is the specie actually present. Thus, highly abrasive Alumina is not present in significant quantities.

\subsection{Hydraulics}

\subsubsection{Head Requirements}

Transfer Pumps - Transfer pumps shall be specified to have a maximum design head and flow capability of 450 feet Total Dynamic Head at $140 \mathrm{gpm}$. However, the pump specification should indicate the different possible system curves that a pump must be capable of matching without damage to the pump or piping system. Figure 1 provides an example of a graph that was contained in a recent specification for a the new generation transfer pump, Specification for Prototype Tank Farm Transfer Pumps with Submersible Motor, WHC-S-0238, Rev. 1 (Hauck 1994). The calculations used to develop this criteria is found in Supplemental Design Calculations Document - Prototype Transfer Pump Calculations, WHC-SD-WM-ER-340, Rev. 0 (Ulbricht 1994). This type of information allows the pump manufacturer to match the pump performance characteristics at different operating speeds to the curves.

The operating philosophy established is that a transfer pump should be sized to meet the most tortuous expected routing for its location. Then for routes with less head loss, a variable speed device shall be used to lower the pump operating curve to the system head curve so that operation is near the best efficiency point. Further justification for this requirement is contained in section 4.2 .1 .

To protect the transfer lines from pressure beyond that allowed by the authorization basis, pump shut-off head should be limited to below 500 feet. Since no definitive analysis has been completed to identify a system-wide maximum head, engineering judgement was used to establish this criteria (see section 4.6.5). 
WASTE TANK FARM SYSTEM CURVES

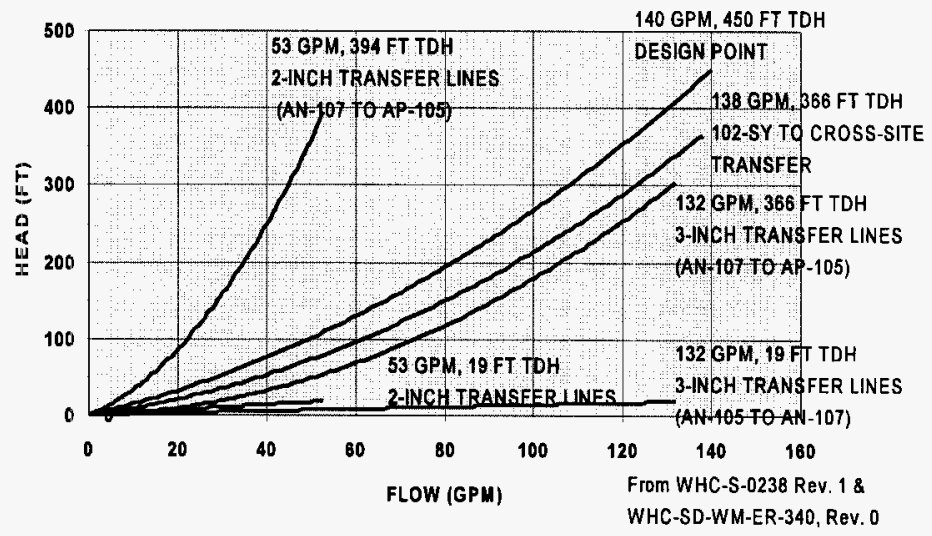

Figure 1. Transfer System Curves

\subsubsection{Flow Rate Requirements}

Transfer Pumps - Desired transfer pump flow rates are dictated by the minimum fluid velocity required to keep particles suspended in the fluid and prevent line plugging. This minimum fluid velocity has been determined to be approximately five to six feet per second. For three-inch pipe, this dictates a flow rate of approximately $140 \mathrm{gpm}$; for twoinch pipe, the minimum flow rate is approximately $50 \mathrm{gpm}$ (see Figure 1).

The determination of adequate minimum flow rate to assure that transfer lines do not plug when transporting solids is not a clearly defined science. This is due to the variety of wastes contained in the DSTs and incomplete waste characterization information. Project W-058, Replacement Cross-Site Transfer System, generated a PNNL letter report entitled, Defining Waste Acceptance Criteria for the Hanford Replacement Cross-Site Transfer System, PNNL-11146, UC-2030 (Hudson 1996). This report delineates the process for characterizing the waste and determining head and flow requirements and other critical parameters that will assure non-plugging of the cross-site transfer line prior to transfers. 


\subsection{3 $\quad \mathrm{U}_{0} \mathrm{D}$}

Mixer Pumps - The velocity-diameter product $\left(\mathrm{U}_{0} \mathrm{D}\right)$ for mixer pumps should not exceed $29.4 \mathrm{ft}^{2} / \mathrm{sec}$. Basis for the $\mathrm{U}_{0} \mathrm{D}$ value selected is found in PNNL Letter Report 7W21-8715 entitled, Development and Demonstration of Technology for Retrieving Waste From Double-Shell Tanks, Pilot Scale Retrieval Tests Using Simulated NCAW (Fow 1987). Pumps exceeding $\mathrm{U}_{0} \mathrm{D}$ requirements of $29.4 \mathrm{ft}^{2} / \mathrm{sec}$ most likely will not fit through existing 42 -inch risers. Impingement forces generated by pumps with $U_{0} D$ 's greater than $29.4 \mathrm{ft}^{2} / \mathrm{sec}$ could over stress and damage internal tank components. In all cases, analysis should be performed to determine the affects of impingement forces on in-tank components.

\subsubsection{Net Positive Suction Head, available}

Mixer Pumps -The Net Positive Suction Head, available (NPSHa) has been calculated based on an assumed fluid level in a tank 3.5 feet above the pump suction, a maximum waste temperature of $185^{\circ} \mathrm{F}$, and atmospheric pressure of 33 feet of water. This results in an NPSHa of 17 feet. This requirement is achievable with current pump technology. Based on engineering judgement, the level is operationally acceptable because at waste levels below 3.5 feet, it is not considered likely that pumps will have to be run at maximum speed.

Transfer Pumps - The NPSHa has been calculated based on an assumed fluid level in the tank of 0 feet above the pump suction, a maximum waste temperature of $185^{\circ} \mathrm{F}$, and atmospheric pressure of 33 feet of water. This results in an NPSHa of 13.5 feet. The minimum submergence is based on adding a level of conservatism to the minimum allowable tank level of 6 inches indicated for most DSTs (see OSD-T-151-00007, Rev./Mod. H017).

It should be noted that NPSHa will vary with each application and that centrifugal pump technology is limited with respect to NPSH required. If the NPSHa is lower than current pump technology can accommodate, then allowances will have to be made. Examples include changing pump speed to reduce the NPSH required or controlling waste ternperature to increase the NPSHa. The engineer responsible for each application should verify that there is a correct match between the system NPSHa and the proposed pump requirements. 


\subsection{Installation Interfaces}

\subsubsection{Dimensional Restrictions}

Mixer Pumps - For most DST applications pumps will be installed into a 42-inch diameter riser. Since risers of this diameter may not be perfectly round, a maximum diameter of 39 inches is recommended for any portion of the pump below the mounting flange. AY tanks have only 34-inch diameter risers; thus, a maximum pump diameter of 31 inches is recommended. These maximum diameters are based on past experience from installing mixer pumps.

Pump length shall be determined on a case-by-case basis and should include consideration of proper elevation of discharge nozzles in relation to sludge depth and tank bottom. If possible, pump designs should adapt well to field length adjustments (accomplished prior to initial installation in a waste tank).

Transfer Pumps - For most applications, pumps must fit through a 12-inch riser; this necessitates a maximum cylindrical envelope diameter of 11 inches below the pump mounting flange. Eleven inches was determined by engineering judgement to be an acceptable margin to allow sufficient clearance within the riser pipes.

A supporting document, Tank Farms Pumping Equipment List, WHC-SD-WM-RPT-025, Rev. 1 (Ash 1993), provides information on the parametric envelope for DST pump installations. It compiles dimensional constraints such as the distance from the riser to the tank bottom and space limitations within pump pits. The information was obtained from H-2 drawings--some of which are considered suspect. Thus, if the pump is to be installed with its suction close to the tank bottom, manual confirmation of the distance is highly recommended. However, if the pump is replacing an existing one of a known length, this verification may not be necessary.

If a pump is being procured as a spare for use in a number of potential tanks, it shall be designed and fabricated such that "field" adjustment of the final pump length can be readily accomplished by Hanford crafts with limited expertise in pump manufacturing techniques. This adjustment shall be accomplished prior to initial installation in a waste tark. The pump shall be supplied with a written procedure for pump length adjustment. Modifications of this type will require run-in testing at the new length.

Transfer pumps are arranged in two configurations at Tank Farms because of the operational need to perform different functions, namely: 
1) General waste transfers involve configuring the pump with its suction as near to the bottom of the tank as possible; called a "stick" pump, as shown in Figure 2. This mode of operation is used for total tank transfers leaving only the heal required by OSDs (approximately six inches in most tanks) or partial tank transfers when there is no concern with transferring a portion of the solids from the lower portion of the tank. This is the most desirable configuration to use for transferring the tank contents after mixing has been completed with a mixer pump since it eliminates the NPSHa problems associated with using a shorter pump that has a floating suction.

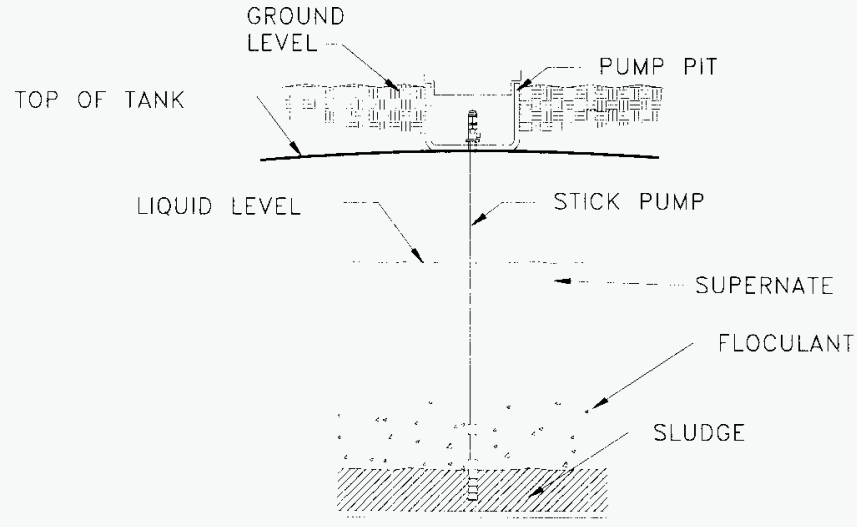

Figure 2. Total Tank Transfer Pumping Arrangement

2) Supernate pumping or decanting, as shown in Figure 3, utilizes a shortened pump with a floating suction; it is often called a "flex float" pump. This mode is used for sludge washing or decanting operations which attempt to leave the settleable solids in the tank while transferring off the "clear" liquid. This configuration is not desirable for total tark transfers because it places the pump suction well above the bottom of the tank thereby reducing the NPSHa below the level that traditional centrifugal pumps can operate reliably. As a result, past experience has shown that total tank transfers are not possible with a flex float pump. Although, it is often possible to pump to some level below the bottom pump impeller; if pumping ceases when the liquid is below the bottom impeller, it cannot be restarted until the waste level is raised. 


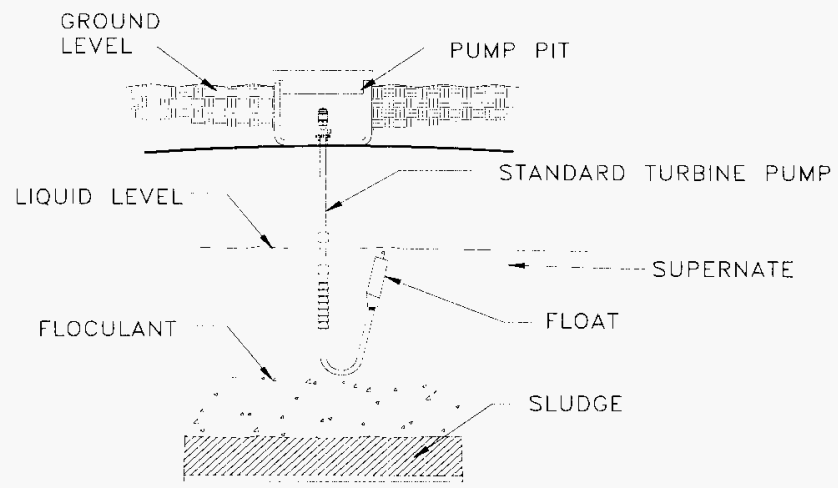

Figure 3. Supernate Pumping Arrangement

Most tanks have only one pump pit. Thus, if a decant pump is installed in a tank to support a sludge washing operation, or is currently installed due to past operational needs, it must be removed from the tank and replaced with a "stick" pump to support a total tank transfer. Since there are currently no processes in place to store used pumps or move them to another tank, the pump must be disposed. This situation represents a deficiency in the current pumping configuration at Tank Farms. A more desirable arrangement would allow a single stick pump to take a suction at different elevations within the tank.

\subsubsection{Weight Limitations}

Mixer and Transfer Pumps - Weight limitations for pumps are tank specific. Limits are based on the maximum tank dome loading which includes a soil depth and equipment inventories installed on top of the tank. A dome load inventory, maintained by the Tank Farm Cognizant Engineer, will provide a source of information from which the acceptable pump weight can be determined. The Tank Farm Cognizant Engineer must be contacted to determine the load margin prior to pump procurement or installation if a new pump or a replacement pump is heavier than its predecessor. 


\subsubsection{Shield Plug}

Mixer Pumps - Mixer pumps shall be supplied by the vendor with a shield plug mounted below the mounting flange. The maximum diameter shall not exceed the limitations specified in section 4.6.1. The Buyer shall analyze the quantity of shielding required based on case specific waste characteristics. The thickness of the shield will be specified to the vendor in inches of concrete or steel. Shielding shall be attached to the pump column at a specified distance below the mounting flange. The location of the shield on the pump column shall be determined by the Buyer's analysis. It may be desirable to make provisions for installation of the shield plug after the pump is in the vertical position in order to reduce weight induced stresses encountered during the up righting process.

The shield plug reduces radiation "shine" through the 42 -inch riser during pump installation and operation. Use of this plug will reduce personnel exposure and is an ALARA requirement.

\subsubsection{Transfer Piping System}

Transfer Pumps - Transfer pump discharge nozzles will be attached to the existing transfer piping system by means of rigid or flexible jumpers within pump pits. The piping system is a network of two inch and three inch double-walled or encased pipes that interconnect the various tanks and Tank Farms. Many different pipelines make up the transfer network. They vary in age, construction, and design and are connected to one another in diversion boxes, valve pits, and pump pits distributed across the Tank Farms complex. A variety of information exists that indicates different maximum design and test pressures for the different lines, but no concise documentation has been identified that: pulls together the pressure limitations and testing constraints for the complete transfer network. Thus, it is not possible to identify a definitive maximum network pressure critical characteristic. This characteristic would clearly identify the need to either limit the maximum shutoff head of pumps or provide a pressure relief/bypass sysiem within pump pits. This is noted as a deficiency of the existing technical basis documentation which creates additional work and complexity in transfer route planning, pump selection, and limits the flexibility of the transfer network.

Without further system-wide analysis, it is recommended that the engineer responsible for installation of a pump research the various routes that it may be possible to use, determine which pipeline has the limiting pressure requirements, compare those requirements to the shutoff head of the pump to be installed to assure that either the pump 
cannot exceed the maximum line pressure or that there is another means to prevent over pressurization.

\subsubsection{Utilities}

Mixer and Transfer Pumps - In all Tank Farms, 3 phase 480 Volt service is available. However, prior to the initial operation of a pump, a case-specific analysis must be completed on the capabilities and capacities of the power distribution system. It is likely that the addition of a new mixer pump(s) or a transfer pump with increased horsepower requirements will result in the need to upgrade the electrical services.

Raw water is available at most pump pits. Line pressure is normally in excess of 100 psi.

Compressed air is available at most farms, however, it is not normally piped to the pump pits. Air is not recommended for use in most pump applications since Tank Farm Operations is attempting to eliminate the need for air in the farms.

\subsubsection{Impingement Forces}

Mixer and Transfer Pumps - Pumps installed in tanks shall be designed to withstand impingement forces placed on them by adjacent mixer pumps. Pumps must be capable of operation during the impingement with no damage or reduction in design life.

It is not possible to provide a definitive force which may be experienced by all pumps because there are many factors that can vary from application to application. The actual force a pump will receive is a function of such factors as the $U_{0} D$ of the pump from which the force is coming, viscosity and rheology of the waste, separation distance, and shape/size of the pump being impinged upon. As a result, the impingement force critical characteristic will be tank specific.

Project W-151 generated a report entitled Stress Cycles and Forces on In-Tank Components Resulting from Mixer Pump Operation in DST 101-AY, WHC-SD-W151ER-001, Rev. 0 (Waters 1993). This is probably the most comprehensive report generated to date on the effects that mixer pumps have on adjacent equipment. It may provide useful information for determining critical characteristics in future pump orders. 


\subsubsection{Protection of Tank/Riser}

Mixer and Transfer Pumps - Installation of pumps requires protection of the tank/riser from a "dropped load" scenario. This requires adding an energy absorbing system to the installation or analysis to show that no damage caused by a drop will result in failure of a safety class feature. The pump specification shall ensure that the pump design allows addition of such a system as required. As an alternative, analysis may be performed prior to completion of the specification which shows that failure of safety class components is not credible due to a pump drop. Impact limiters have been designed for mixer pumps installed by Projects W-151, W-211, and for the tank SY-101 mitigation pump installation.

\subsection{VERIFICATION METHODS}

The following sections define the methods used to verify the critical characteristics in Table 4-1. The recommendations are only a guideline; on proven designs and repeat installation, some of the verifications can be achieved through prior documentation.

\subsection{Inspection (I)}

The inspection method shall be defined as visual or other means of determining the requirement was achieved. It can include standard measurement or laboratory instruments required to achieve accuracy of the inspection.

\subsection{Analysis (A)}

The analysis method shall be defined as engineering calculations using recognized standards and identified assumptions to prove that a requirement can be achieved.

\subsection{Engineering Evaluation (EE)}

The engineering evaluation method shall be defined as an evaluation of design approaches or comparison of requirements to the design that cannot be analyzed by established standards/assumptions. The use of engineering evaluation requires the concurrence of the Buyer to establish if the requirement has been met. 


\section{$5.4 \quad$ Feature Test (FT)}

The feature test shall be defined as a bench test; component tests or tests that must be conducted to gather data to ensure that the design will meet its requirement. Feature test plans shall be reviewed by the Buyer.

\subsection{Acceptance Test (AT)}

The acceptance test shall be defined as the system test of a unit or assembly that demonstrates compliance with the requirements. Acceptance test plans shall be written by the manufacturer and approved by the engineer responsible for the pump procurement.

\subsection{REFERENCES}

Ash, W. R., 1993, Tank Farms Pumping Equipment List, WHC-SD-WM-RPI-025, Rev. 1, Westinghouse Hanford Company, Richland, Washington.

Brockett, M. D., 1995, New Generation Transfer Pump Cost Benefit Analysis, WHC-SD-WMES-365, Rev. 0, prepared by ICF Kaiser Hanford Company for Westinghouse Hanford, Company, Richland, Washington.

Certa, P. J., 1995, Preliminary Retrieval Sequence and Blending Strategy, WHC-SD-W211TDR-001, Rev. 0, Westinghouse Hanford Company, Richland, Washington.

Colton, N. G., 1996, Status Report: Pretreatment Chemical Evaluation-Wash and Leach Factors for the Single-Shell Tank Waste Inventory, Pacific Northwest National Laboratory, Richland, Washington.

40 CFR 264.314, Code of Federal Regulations, Special Requirements for Bulk and Containerized Liquids, Environmental Protection Agency, Washington, D.C.

40CFR 264.315 Code of Federal Regulations, Special Requirements for Bulk and Containerized Liquids, Environmental Protection Agency, Washington, D.C.

40CFR 268.45 Code of Federal Regulations, Treatment Standards for Hazardous Debris, Environmental Protection Agency, Washington, D.C. 
Fow, C. L., et al., 1987, Development and Demonstration of Technology for Retrieving Waste from Double Shell Tanks-- Pilot Scale Retrieval Tests Using Simulated NCAW, 7W21-8715, Rev. 0, Pacific Northwest National Laboratory, Richland, Washington.

Guthrie, R. L., 1996, Aging Waste Facility Ventilation Upgrade, Project W-030 Safety Analysis Reference Report, draft, WHC-SD-WM-SARR-039, Rev. 0, Westinghouse Hanford Company, Richland, Washington.

Hauck, F. M., 1994, Specification for Prototype Tank Farm Transfer Pumps with Submersible Motor, WHC-S-0238, Rev. 0, prepared by ICF Kaiser Hanford Company for Westinghouse Hanford, Company, Richland, Washington.

Hall, M. N., 1996, Life-Cycle Cost Analysis of Advanced Design Mixer Pump, WHC-SD-WMCBA-001, Rev. 0, Westinghouse Hanford, Company, Richland, Washington.

Hudson, J. D., 1996, Defining Waste Acceptance Criteria for the Hanford Replacement CrossSite Transfer System, PNNL-11146 UC-2030, Pacific Northwest National Laboratory, Richland, Washington.

ICF K.H, 1994, A-E Standard - Civil/Structural, Design Loads for Facilities, GC-LOAD-01, ICF Kaiser Hanford Company, Richland, Washington

Leach, C. E., 1996, Flammable Gas/Slurry Growth Unreviewed Safety Question: Justification for Continued Operation for the Tank Farms at the Hanford Site, WHC-SD-WM-JCO007, Rev. 1, Westinghouse Hanford Company, Richland, Washington.

MacLean, G. T., 1996, Pretreatment Applied Engineering, Corrosion Assessment for Tank Materials: 1995 Final Report, WHC-SD-WM-TI-765, Rev. 0, Westinghouse Hanford Company, Richland, Washington.

McCormick, W. A., 1995, Specification for Contaminated Equipment Burial Container, WHCS-0402, Rev. 0, Westinghouse Hanford Company, Richland, Washington.

Orem, R. M., et al., 1996, TWRS Privatization Process Technical Baseline, WHC-SD-WM-TI774, Rev, 0, Westinghouse Hanford Company, Richland, Washington.

Rieck, C.A., 1995, Title I Design Summary Report, Initial Tank Retrieval Systems, Project W-211, WHC-SD-W211-TDR-001, Rev. 0B, Westinghouse Hanford Company, Richland, Washington. 
Ulbricht, R. S., 1994, Supplemental Design Calculations Document - Prototype Transfer Pump Calculations, WHC-SD-WM-ER-340, Rev. 0, prepared by ICF Kaiser Hanford Company for Westinghouse Hanford, Company, Richland, Washington.

Waters, E. D., et al., 1993, Stress Cycles and Forces on In-Tank Components Resulting From Mixer Pump Operation in DST 101-AZ (Design Input), WHC-SD-W151-ER-001, Rev. 0, Westinghouse Hanford Company, Richland, Washington. 


\section{Appendix A}

Applicable Codes for Centrifugal Pump Procurement 


\section{APPLICABLE CODES FOR CENTRIFUGAL PUMP PROCUREMENT}

\section{Use latest edition}

\begin{tabular}{|c|c|c|}
\hline 1. & $\begin{array}{l}\text { American Petroleum Institute (API) } \\
\text { Standard } 610 \text {, Seventh edition or later }\end{array}$ & "Centrifugal Pumps for General Refinery Service" \\
\hline \multirow[t]{6}{*}{2.} & $\begin{array}{l}\text { American Society of Mechanical Engineers } \\
\text { (ASME) } \\
\text { B\&PVC }\end{array}$ & Boiler and Pressure Vessel Code, 1992 or later \\
\hline & Section IX & Welding and Brazing Qualifications \\
\hline & $\mathrm{B} 30.20$ & Below the Hook Lifting Devices \\
\hline & $\mathrm{B} 331.1$ & Power Piping \\
\hline & $\mathrm{B} 31.3$ & Chemical Plant and Petroleum Refinery Piping \\
\hline & Y'14 Series & $\begin{array}{l}\text { Engineering Drawings and Related Documentation } \\
\text { Practices }\end{array}$ \\
\hline \multirow[t]{2}{*}{3.} & $\begin{array}{l}\text { American Society of Nondestructive Testing } \\
\text { (ASNT) }\end{array}$ & \\
\hline & SNT-TC-1A & Recommended Practice \\
\hline \multirow[t]{2}{*}{4.} & American Welding Society (AWS) & \\
\hline & D1.1 & Structural Welding Code - Steel \\
\hline 5. & $\begin{array}{l}\text { Hydraulic Institute }(\mathrm{HI}) \\
\text { Hydraulic Institute Standards }\end{array}$ & \\
\hline 6. & $\begin{array}{l}\text { National Electrical Manufacturer's } \\
\text { Association (NEMA) }\end{array}$ & \\
\hline & MG-1 & Motors and Generators \\
\hline 7. & $\begin{array}{l}\text { National Fire Protection Association (NFPA } \\
70 \text { ) }\end{array}$ & National Electrical Code (NEC) \\
\hline 8. & $\begin{array}{l}\text { International Conference of Building Officials } \\
\text { Uniform Building Code (UBC) }\end{array}$ & Seismic Criteria \\
\hline
\end{tabular}


TANK Farms Pump CRITICAl Characteristic and SPECIFICATION

WHC-SD-WM-DGS-006, Rev. 0

GUIDE - Report No. 961145-001, Rev. 0 January 1997

Appendix B

Basis for Waste Simulant Choice 


\section{NEW GENERATION TRANSFER PUMP}

\section{BASIS FOR WASTE SIMULANT CHOICE}

AUGUST 15, 1995

\section{PURPOSE}

The NGTP wear test program is intended to validate the pump design and ensure that critical areas of the pump and motor will perform satisfactorily for the specified life.

This will be accomplished by testing the pump bearing materials, the materials used in high velocity hydraulic areas and the motor can materials using a simulant that is representative of typical Hanford tank waste.

This test does not involve a completely assembled pump but instead uses a test rig that produces fluid velocities and loads that are the same as those found in the actual pump.

\section{BACKGROUND}

A test program to evaluate the wear characteristics of different materials was proposed as part of the pump vendors efforts to ensure a design that would meet our specified requirements. This involved testing bearing materials as well as materials for high velocity hydraulic areas.

Initially a very conservative but aggressive simulant was chosen by the pump vendor that had a high concentration of Alumina $\left(\mathrm{Al}_{2} \mathrm{O}_{3}\right)$ with a hardness of 9 on the Moh's scale.

This initial simulant choice was based on attempts to satisfy concerns expressed by engineers at both Hanford and Savannah River that large quantities of Alumina may have been added to some of the waste tanks.

A successful test with this simulant would have qualified the equipment for virtually any service, however, it was not truly representative of the waste at Hanford. Actual tests performed with this simulant demonstrated a high level of wear on bearing materials over a short period of time, resulting in a re-assessment of the simulant to be used.

A closer look at the characterization work done to date at Hanford resulted in a revised simulant that more closely resembles the Hanford waste but is still conservative. 


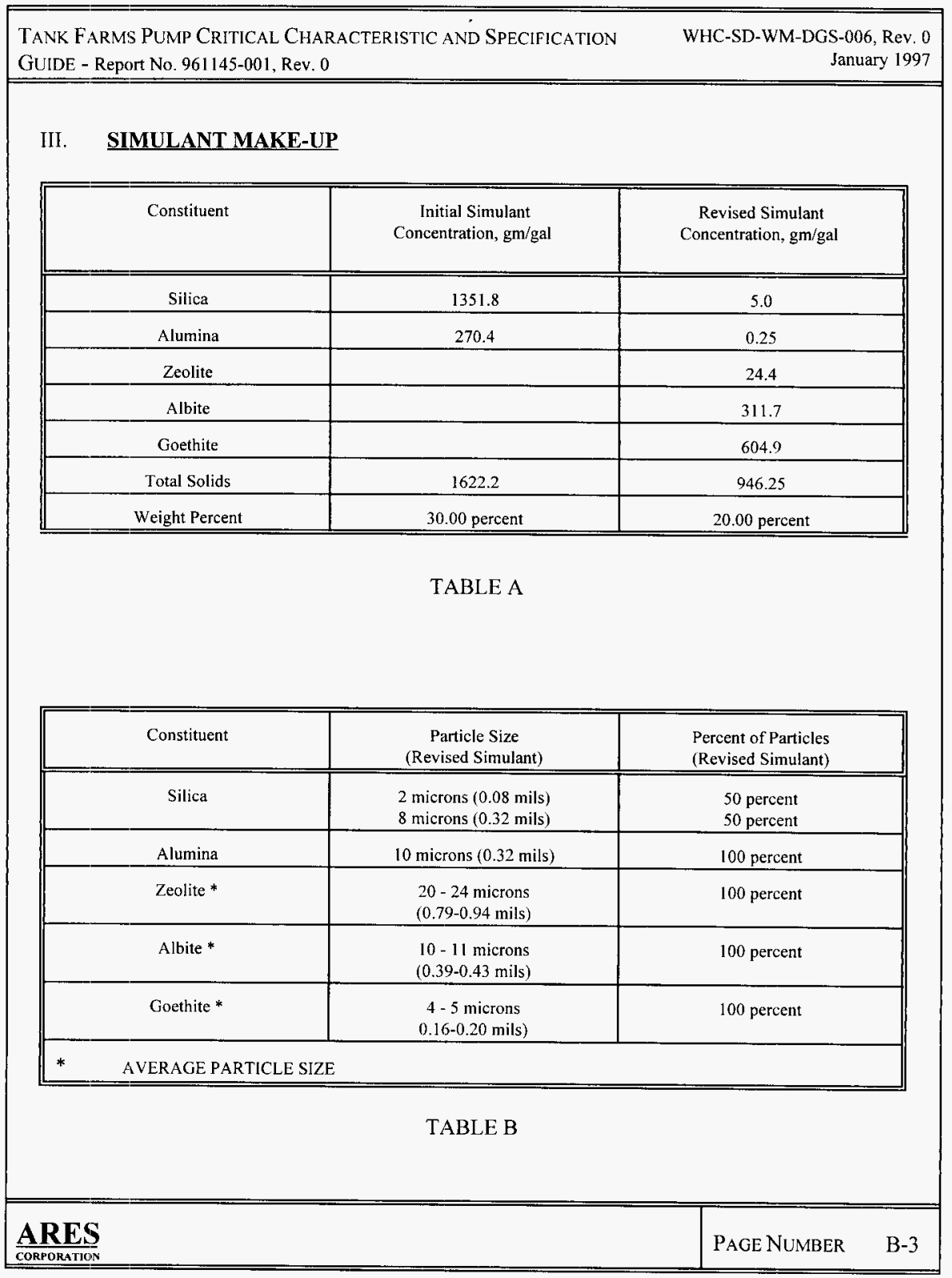




\section{BASIS FOR SIMULANT CHOICE}

\section{A. INITIAL SIMULANT}

The initial simulant was based on information from Hanford and Savannah River that suggested significant amounts of Aluminum Oxide, $\mathrm{Al}_{2} \mathrm{O}_{3}$, in the form of Corundum (Alumina) was present in the waste. The pump vendor proposed a simulant formula based on this information and a desire to qualify the pump and motor for the "worst case" condition.

The testing performed with this simulant was unsatisfactory and a review of the simulant by engineers at WHC, ICF KH, and PNNL indicated that it was not representative of the majority of Hanford wastes. It was concluded that the testing done with this simulant did not provide meaningful data for Transfer Pump qualification.

\section{B. FINAL SIMULANT}

The final simulant was based on documents that compile and review tank waste characterization data and interviews with Hanford personnel who are responsible for waste characterization. The final simulant attempts to more accurately represent the wear characteristics of the tank contents.

The data was obtained from Radionuclide and Chemical Inventories for the Double Shell Tanks', Tank Waste Treatment Science: Report for the First Quarter FY 1994 ${ }^{2}$, Efficient Separations and Processing Integrated Program - Hanford Sludge Chemistry Evaluation ${ }^{3}$, and WHC Internal Memo No. 74620-95-018, dated May 19, $1995^{4}$.

While much is yet to be learned about the chemistry of the Hanford Waste Tanks, this information represents the latest thinking and testing done by WHC and PNNL engineers.

\section{SUMMARY}

It is anticipated that successful testing with the final simulant chosen will provide us with a pump that will meet an operating life of 5,000 hours for Hanford Transfer Pump applications. 
Attachment A provides a systematic assessment of four alternatives for simulant selection. It concludes that the simulant described in this document is the best alternative.

As an option for further pump development, additional wear testing with a simulant modified for even more severe duty may be contracted with our pump vendors. Over the coming months and years our knowledge of the composition of the waste at Hanford will increase dramatically, allowing us to simulate the actual waste much more accurately.

\section{REFERENCED DOCUMENTS}

1. Oscarson, E. E. and L. A Tusler, July 30, 1993, Radionuclide and Chemical Inventories for the Double Shell Tanks, WHC-SD-WM-TI-543, Rev. 1, Westinghouse Hanford Company, Richland, Washington.

2. LaFemina, J. P., et al, January 14, 1994, Tank Waste Treatment Science: Report for the First Quarter FY 1994, TWRSPP-94-001, Pacific Northwest National Laboratory, Richland, Washington.

3. Colton, N. G., August 1993, Efficient Separations and Processing Integrated Program - Hanford Sludge Chemistry Evaluation, Pacific Northwest Laboratory, Richland, Washington.

4. MacLean, G. T., May 19, 1995. In-Tank Processing of Hanford Wastes, WHC Internal Memo No. 74620-95-018, Westinghouse Hanford Company, Richland, Washington.

F. Marshall Hauck, PLE, ICF KH 


\section{ATTACHMENT A \\ WEAR TESTING SIMULANT SELECTION ASSESSMENT}

I. BACKGROUND

As part of their effort to meet the WHC Design Specification for the NGTP, the pump vendor has elected to perform wear tests of several different potential bearing materials. They have designed a test rig that simulates the physical and hydraulic configuration of the radial sleeve bearings that are found in the motor.

To achieve realistic results, they needed to develop a simulant that resembled the Hanford waste. Specifically, the wear characteristics of the waste were important. Data available through the Pump Specification was not specific enough to define a simulant so a mutual effort was undertaken by WHC and the pump vendor to review the characterization data available and come up with a realistic waste simulant.

\section{POTENTIAL PROBLEMS}

The primary problem occurs when the simulant chosen is less abrasive than the actual waste. If this occurs, and the actual waste is more abrasive, the bearing wear rate will increase and the pump life may be shortened. If the pump life is shortened, the overall program costs may go up, however, in this situation it will not increase the risk to the health and safety of the public.

\section{MODE OF FAILURE}

In the event extreme bearing wear results in pump failure, the increase in bearing clearance due to wear will result in a change in the pump vibration characteristics and pump performance. In addition, high bearing wear may be accompanied by high motor amperage that results from the grinding effect of hard particles. All of these values are typically monitored and provide advance information that forecasts pump failure. Failure without warning is not expected.

\section{ALTERNATIVES INVESTIGATED}

A. No simulant would be required. Rely on existing wear data from vendors and engineering reports for bearing material selection. 
- The confidence level that the equipment would meet the design life would be low because experience with product lubricated bearings in this type of service is minimal.

- $\quad$ Because the wear characteristics of the waste will vary from tank to tank or even within a given tank, with the worst conditions occurring infrequently, pumps designed without wear testing would probably meet the design life in many instances.

B. Prepare a tank specific simulant

- Would provide a high degree of confidence for the specific tank involved. Depending on how the tank characterization compares to other tanks, the testing may or may not be of value.

C. Based on a worst case scenario where a significant number of tanks would contain very abrasive solids, a very conservative simulant would be used, i.e., one with high concentrations of $\mathrm{Al}_{3} \mathrm{O}_{2}$ (Carborundum).

- Based on current understanding of product lubricated bearings, the risk of rapid bearing wear is high with virtually any bearing material because the simulant is essentially grinding compound.

- If the testing is successful, you would have a very high degree of confidence that the pump would meet the design life for any conceivable condition found at Hanford.

- If tests are not successful, the product lubricated bearing design will need to be replaced with an alternative design involving the addition of water for bearing lubrication. This complicates the design and the addition of water increases the overall waste processing cost.

D. Based on current Hanford waste characterization work, design a simulant that attempts to model the majority of waste as we currently understand it with specific emphasis on the wear properties of the constituents. (See Table A on page B-3 for simulant make-up and use the revised simulant)

- While this approach may not cover every conceivable waste composition, it would represent the bulk and will be more conservative than most. 
- Based on current characterization data. Assumes that data gathered from a few tanks resembles the waste in others.

- $\quad$ Leaves open the remote possibility where the pumps might encounter abrasive waste that causes a higher wear rate than the simulant does.

\section{CRITERIA FOR EVALUATING THE ALTERNATIVES}

1. Builds user's confidence in the pumps ability to meet the design life.

2. Provides the best value for the money being spent.

3. Minimizes the risk of premature pump failure.

4. Provides a realistic possibility for the use of product lubricated bearings.

5. Makes no change in the risk to the public.

6. Allows for maintaining existing production schedules.

Criteria are valued as follows:

$-2 \quad$ Criteria not met

$-1 \quad$ Parts of the criteria have not been met

$0 \quad$ Criteria has no overall effect on the alternative

+1 Parts of this criteria are met

+2 Criteria completely met

CRITERIA NO.

\begin{tabular}{||c|c|c|c|c|c|c|c||}
\hline ALT. NO. & 1 & 2 & 3 & 4 & 5 & 6 & TOTAL \\
\hline A & -2 & 0 & -1 & -1 & +2 & +2 & 0 \\
\hline B & -1 & -1 & +1 & +1 & +2 & -1 & +1 \\
\hline C & +2 & +1 & +2 & -1 & +2 & -1 & +5 \\
\hline D & +1 & +2 & +1 & +2 & +2 & +2 & +10 \\
\hline
\end{tabular}




\section{SUMMARY}

Based on this evaluation, Alternative $\mathrm{D}$ will be recommended for use by the pump vendor for their wear testing program for the New Generation Transfer Pump. 


\begin{tabular}{|c|c|c|c|c|c|}
\hline \multicolumn{6}{|c|}{ DISTRIBUTION SHEET } \\
\hline To & \multirow{2}{*}{\multicolumn{3}{|c|}{$\begin{array}{l}\text { From } \\
\text { TWRS Facility Operations } \\
\text { Design Authority }\end{array}$}} & \multicolumn{2}{|c|}{ Page 1 of 1} \\
\hline Distribution & & & & \multicolumn{2}{|c|}{ Date $1 / 16 / 97$} \\
\hline \multicolumn{4}{|l|}{ Project Title/Work Order } & \multicolumn{2}{|c|}{ EDT No. 613059} \\
\hline LLCE Disposal Program & & & & \multicolumn{2}{|c|}{ ECN No. } \\
\hline Name & MSIN & $\begin{array}{l}\text { Text } \\
\text { With All } \\
\text { Attach. }\end{array}$ & Text Only & $\begin{array}{l}\text { Attach./ } \\
\text { Appendix } \\
\text { Only }\end{array}$ & $\begin{array}{c}\text { EDT/ECN } \\
\text { Only }\end{array}$ \\
\hline $\begin{array}{l}\text { Document Control } \\
\text { J. W. Bailey } \\
\text { T. R. Benegas } \\
\text { M. D. Brockett } \\
\text { D. W. Crass } \\
\text { F. M. Hauck } \\
\text { G. P. Janicek } \\
\text { D. L. Lamberd } \\
\text { G. A. Leshikar } \\
\text { G. A. Meyer } \\
\text { R. J. Murkowski } \\
\text { C. A. Rieck } \\
\text { S. H. Rifaey } \\
\text { R. L. Schlosser } \\
\text { C. P. Shaw } \\
\text { P. A. Titzler } \\
\text { J. E. Van Beek }\end{array}$ & $\begin{array}{l}\text { A3-88 } \\
\text { S2-48 } \\
\text { S2-24 } \\
\text { S2-47 } \\
\text { H5-68 } \\
\text { S2-47 } \\
\text { R1-56 } \\
\text { H5-61 } \\
\text { S2-24 } \\
\text { S2-48 } \\
\text { H5-03 } \\
\text { S2-48 } \\
\text { Rl-56 } \\
\text { R1-56 } \\
\text { S2-24 } \\
\text { R1-56 } \\
\text { S2-48 }\end{array}$ & 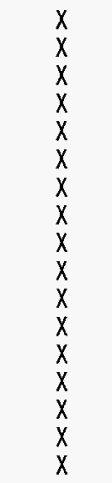 & & & \\
\hline
\end{tabular}

